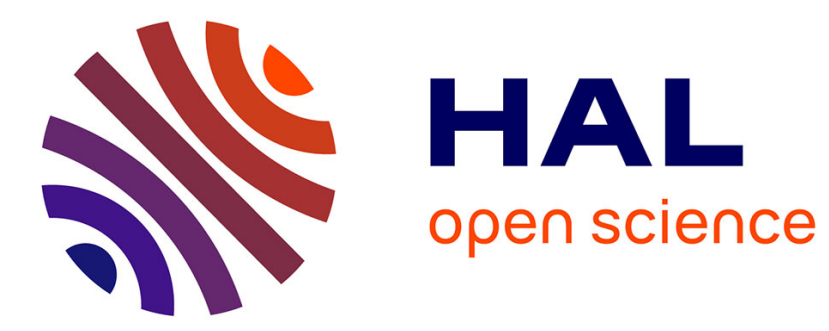

\title{
Sampling and quantitative analysis methods in anthracology from archaeological contexts: Achievements and prospects
}

Ceren Kabukcu, Lucie Chabal

\section{- To cite this version:}

Ceren Kabukcu, Lucie Chabal. Sampling and quantitative analysis methods in anthracology from archaeological contexts: Achievements and prospects. Quaternary International, 2020, Charcoal Science in Archaeology and Palaeoecology, 7th International Anthracology Meeting, University of Liverpool, UK, 2-6 Sept. 2019, 10.1016/j.quaint.2020.11.004 . hal-03012766

\section{HAL Id: hal-03012766 \\ https://hal.science/hal-03012766}

Submitted on 2 Dec 2020

HAL is a multi-disciplinary open access archive for the deposit and dissemination of scientific research documents, whether they are published or not. The documents may come from teaching and research institutions in France or abroad, or from public or private research centers.
L'archive ouverte pluridisciplinaire HAL, est destinée au dépôt et à la diffusion de documents scientifiques de niveau recherche, publiés ou non, émanant des établissements d'enseignement et de recherche français ou étrangers, des laboratoires publics ou privés. 
See discussions, stats, and author profiles for this publication at: https://www.researchgate.net/publication/346006904

\section{Sampling and quantitative analysis methods in anthracology from archaeological contexts: Achievements and prospects}

Article in Quaternary International · November 2020

DOI: 10.1016/j.quaint.2020.11.004

\section{CITATIONS}

2 authors:

Ceren Kabukcu

University of Liverpool

28 PUBLICATIONS 218 CITATIONS

SEE PROFILE
READS

115

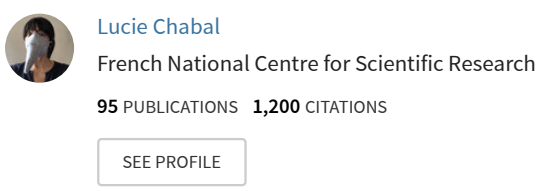

Some of the authors of this publication are also working on these related projects: 
Citation: Kabukcu, C. and Chabal, L., 2020. Sampling and quantitative analysis methods in anthracology from archaeological contexts: Achievements and prospects. Quaternary International. https://doi.org/10.1016/j.quaint.2020.11.004 (In press, available online. Part of the Special Issue: Charcoal Science in Archaeology and Palaeoecology) (C) $<2020\rangle$. This manuscript version is made available under the CC-BY-NCND 4.0 license http://creativecommons.org/licenses/by-nc-nd/4.0/

\section{Sampling and quantitative analysis methods in anthracology from archaeological contexts: achievements and prospects}

Corresponding author: Ceren Kabukcu, Department of Archaeology, Classics and Egyptology, University of Liverpool, United Kingdom

Email: C.Kabukcu@ liverpool.ac.uk

Lucie Chabal, ISEM, University of Montpellier, CNRS, IRD, EPHE, Montpellier, France. Email: lucie.chabal@umontpellier.fr
Abstract
This paper provides a critical review of the main methodological achievements in sampling and quantitative analysis in anthracology, the study of wood charcoal macro-remains from archaeological contexts. The application of appropriate sampling protocols is a prerequisite for the study of all types of archaeo-anthracological assemblages, particularly when it comes to the study of wood fuel waste. Sampling directly impacts the quantitative taxonomic composition of a charcoal assemblage and its representativeness with regard to reconstructing ancient woodland composition. The selection of contexts and deposits appropriate for this purpose, the spatial sampling of charcoal scatters, sieving methods and mesh size, what constitutes optimal sample size and the outcomes of charcoal fragmentation, are all discussed. Provided that appropriate methods are followed, the case for the palaeoecological representativeness of archaeo-anthracological fuel waste deposits is argued in detail. This also includes a discussion of the contribution of laboratory experiments to understanding the impacts of combustion and post-depositional processes on archaeological charcoal preservation and the implications of fuelwood properties for wood collection. We argue that ancient firewood use was predicated principally on wood availability in past vegetation and its interdependence with ancient landscape management practices. Lastly, we discuss the application of multivariate methods in anthracology, and the insights they may provide for reconstructing archaeological charcoal taphonomy, and past woodland vegetation and fuel uses. 
Key-words: charcoal analysis, quantification, palaeoenvironmental reconstruction, palaeoecology, fuel wood, multivariate analyses

\section{Introduction: a brief historical background to anthracological methodology}

The present paper follows on from over four decades of research and debate into the quantification potential of anthracological remains. The first taxonomic and ecological studies of wood charcoals from archaeological contexts date back to the end of the 19th century and the first half of the 20th century, in Europe and North Africa (see detailed overviews by Keepax, 1988; Castelletti, 1990; Asouti, 2002; Kabukcu, 2018a and references therein). Although several theoretical arguments for and against the palaeoenvironmental representativeness of archaeological wood charcoals were put forward during this early period (e.g., Salisbury and Jane 1940; Godwin and Tansley 1941; and somewhat later Western 1971), the limited scale and precision of charcoal field sampling did not leave much scope for rigorous applications. This state of affairs changed radically in the 1980s, under the influence of Jean-Louis Vernet and his doctoral students at Montpellier (France). The so-called 'Montpellier school' ushered in major methodological developments that made possible for the first time the quantitative exploration of charcoal macro-remains for the purpose of palaeoenvironmental reconstruction. Vernet's students were actively involved in archaeological field projects designing and testing different sampling methods, often supplemented by experimental studies that were built into several $\mathrm{PhD}$ projects (including, in alphabetical order, E. Badal, E. Bazile-Robert, L. Chabal, A. Durand, L. Fabre, I. Figueiral, G. Fiorentino, E. Grau, C. Heinz, V. Izard, I. Krauss-Marguet, C. Machado, C. Newton, P. Poirier, O. Rodriguez, T. Ros, R. Scheel-Ybert, M.-E. Solari, C. Tardy, M. Tengberg, I. Théry-Parisot, S. Thiébault, P. Uzquiano, and others).

The distinctive contributions of the 'Montpellier school', aided by contemporaneous advances in optical microscopy (Leney and Casteel, 1975), emphasised the necessity to study sufficiently large charcoal assemblages with due attention to the spatial representativeness of field sampling, distinguishing between concentrated and dispersed charcoal deposits derived from fuel wood debris, the analysis of fragmentation patterns, the advantages of sieving over hand-picking in the case of charcoal scatters (with the exception of certain low-density prehistoric occupation deposits and/or preservation conditions as seen in arid and semi-arid environments) and the palaeoecological representativeness of the relative frequencies of charcoal taxa. The outcomes of this research effort have been published extensively in previous International Anthracology Meetings starting from the first one held in 1991 in 
Montpellier (Vernet, 1992; Thiébault, 2002; Fiorentino and Magri, 2008; Badal et al., 2012; Damblon, 2013; Ludemann and Nelle, 2017, 2018). Several anthracologists originally trained in Montpellier, as listed above, founded laboratories in France and other countries, developed new methods, compiled and expanded available reference materials (wood anatomy atlases) and engaged in palaeoecological research in different world regions also involving the interdisciplinary study of different types of palaeoenvironmental proxies (e.g., charcoal alongside seed and fruit remains, pollen and phytoliths). At the same time, other scholars working with charcoal in Europe and beyond, expanded the global reach of anthracology as a distinctive discipline within the parent disciplines of environmental archaeology and palaeoecology (E. Asouti, L. Castelletti, F. Damblon, F. Follieri, D. Marguerie, M. Moskaldel Hoyo, T. Ludeman, O. Nelle, K. Neumann, M. Ntinou, R. Piqué, F.H. Schweingruber, G. Willcox to name a few). More recent cohorts of anthracologists (too many to list here by name) have since then contributed important methodological and theoretical innovations which are not possible, due to the limited journal space, to enumerate and much less summarise here.

The first part of the paper takes stock of the fundamental methodological principles of anthracology, and reiterates their importance for the scientific integrity of the discipline as a whole. These principles form the basis for all developments in charcoal science, both in recent years but also with a view to the future development of the discipline. Charcoal found in archaeological sites may represent the remains of artefactual wood and timber used in construction or fuel wood use, which can provide different types of information relative to the original use of wood. The focus of the present paper are anthracological remains that can provide appropriate data for palaeoecological interpretation. We also discuss sampling and sub-sampling protocols, charcoal fragmentation and taphonomy and various other factors contributing to wood fuel selection and use. We conclude by critically evaluating the palaeoecological representativeness of anthracological remains, and presenting some more recent developments in quantitative analyses in anthracology.

\section{Field sampling and charcoal quantification}

\subsection{The importance of field sampling and recovery methods}

Several studies conducted in the 1980s and 1990s have demonstrated the importance of sampling vis a vis the integrity of anthracological datasets and, in relation to it, the 
feasibility of palaeoenvironmental reconstruction (contributions of authors on each topic are cited below). The latter is entirely dependent on every step of the methodological sequence, from the selection of appropriate archaeological contexts and deposits to sample in the field through to the quantitative description of the taxonomic composition of the anthracological assemblage (i.e., the taxon frequency spectra).

Depending on preservation conditions and/or deposit types (e.g., in situ carbonised timber remains, artefactual wood, other in situ wooden items placed in funerary contexts) and specific research objectives, it may be necessary or appropriate to employ hand-picking for the recovery of wood charcoal remains. Nevertheless, following on from established archaeobotanical methods (Pearsall 2000), in anthracology as well the use of machine-assisted flotation for sample processing in the field enables processing large volumes of sediment with relative ease and speed compared to manual wet-sieving and dry-sieving. Furthermore, flotation also results in less re-fragmentation of charcoal compared to manual wet-sieving (Chabal, 1989). Some studies have shown that charcoal fragments with greater density (vitrified and/or heavily mineralised) may not be fully recovered in the light-fraction obtained via machine-assisted flotation (Scheel-Ybert, 1998). Provided that charcoal fragments are also retrieved from the heavy residue (non-floating) fractions, the taxon ratios obtained by flotation resemble closely those obtained by dry sieving in the field (Chabal, 1989; ScheelYbert, 1998, 2002; Bourquin-Mignot et al., 1999; Théry-Parisot et al., 2010a). Perhaps the most important practical benefit of flotation is the retrieval of additional ecofacts and artefacts such as other charred plant remains, bone, lithics etc., through a single streamlined recovery process, which makes it the preferred method of recovery for a wide range of archaeological field projects.

\subsection{Identifying and evaluating wood use}

The first rule of anthracological field sampling relates to the correct identification of the different taphonomic pathways that led to charcoal deposition in a given anthracological context, with particular emphasis on the types of wood uses (e.g., domestic fuel wood use, construction timber, etc.) represented in the sampled archaeological deposits. This is achieved through a detailed consideration of the archaeological attributes of each context and deposit, including for example artefact distributions and densities, and the presence or absence of particular features (e.g., buildings, structures, postholes, hearths, open spaces, food processing and consumption waste areas, artefact concentrations, etc.). 
It is important to emphasise here that the taxonomic composition of a charcoal assemblage cannot be used as a criterion for assessing past wood uses. Different wood species may have been used in certain contexts as timber, in others as fuel, and in yet others as both. For example, we have found Salicaceae charred timber remains at Neolithic Boncuklu (central Turkey) whereby the same taxon was also one of the dominant fuel wood taxa (Asouti and Kabukcu, 2014; Baird et al., 2018; Kabukcu, in press) and also poplar poles at Coudounèu (southern France) during the Iron Age, where the dominant vegetation was a Mediterranean oak grove (Chabal, 1996). In the city of Ghent (northern Belgium) Alnus was used as fuel and timber in the 12th century, interpreted by Deforce (2017) as an effect of timber and fuel wood shortage. Isolated charcoal finds of such taxa could be erroneously interpreted as unrelated to architectural contexts, since from a structural point of view they represent poor choices in terms of timber strength and durability. However, they could still have been selected for making timber posts. Poplar wood was one of the timber species of choice in traditional central Anatolian mudbrick architecture until well into the $20^{\text {th }}$ century, due to the straightness of poplar poles, the ease with which they can be worked, and their fast growth rates (Stirling, 1965). This last example also demonstrates the point that, although fuel wood and timber remains do not provide the same level of information about ancient woodland composition, they can nonetheless be approached from the dual perspective of wood use and environmental management.

Once contextual criteria for determining whether wood charcoals represent fuel waste debris, or other uses, have been met, it is important to exercise caution when it comes to evaluating species selection. As a general rule, it is hard to argue that certain wood taxa are best suited to specific tasks (e.g., for smoking, drying, etc.). Théry-Parisot (2001) has observed that fuel wood selection for particular tasks tends to vary as much as the number of the communities described by ethnographic studies; i.e., species selection is rarely based on objective parameters. Henry (2011) has shown, for example, that the choice of fuel species by Alaskan Inuit communities for smoking fish to enhance their flavour is characterised by strong local preferences that vary considerably between different groups and even individuals belonging to the same group. These examples show that invoking perceived qualities of certain wood species as 'good' fuel or timber, thus deducing their 'selection' as 'preferred' species, is inappropriate without considering first the socioeconomic and environmental contexts of past wood uses including woodland composition, habitats, and landscape uses. 
What constitutes 'good fuel' and the energy returns of the different species are contested issues to which we return below (see 3.1).

For the purpose of palaeoenvironmental reconstruction, charcoals originating from the remains of domestic fuel wood use are the most appropriate source of data. Domestic fuel collection and consumption are practiced repeatedly: fires burn daily, and fuel waste debris is routinely discarded. Enormous volumes of wood are consumed in these fires, which leave behind little charred residue as most wood is converted to ash. Charcoal scatters found in each layer or phase represent a palimpsest of repeated episodes of fuel wood use and the discard of charred debris, in which most of the wood has been reduced to ashes on a routine basis. As a result of this stochastic process, which leaves behind very little charcoal residue from each fire, the frequencies of taxa used as fuel wood have been averaged over successive years or decades (or even longer time spans in the case of Palaeolithic sites). Specifically, even if we assume that a certain species might have been occasionally selected for a specific short-lived task, the anthracological signature of its use has very likely disappeared in the ashes or has been diluted to the point of having been erased by subsequent episodes of fuel wood collection and use.

Valuable palaeoenvironmental information can also be obtained from non-domestic fuel wood use, for example pottery kilns (Chabal and Laubenheimer, 1994; Chabal, 1997, 2001; Vaschalde and Chabal, in press), charcoal production kilns (Fabre, 1996; Bonhôte et al., 2002; Nelle, 2003; Ludemann, 2010; Paradis-Grenouillet, 2012), lime kilns (Vaschalde 2018), funeral cremations (Cenzon-Salvayre, 2014; Moskal-del Hoyo, 2012) and mining and metallurgical contexts (Izard, 1999; Py, 2009; Paradis-Grenouillet, 2012; Py et al., 2013) all of which can provide direct evidence of woodland composition, structure and/or the management of ancient woodlands. The systematic sampling of fuel wood debris from potters' kilns and lime kilns can provide very accurate snapshots of the fuel species spectra, despite the oxidising conditions and the high temperatures reached in these hearth environments often leading to limited charcoal preservation. In domestic or specialist fireplaces the objective is to use fuel wood in the most optimal and efficient manner, that is by burning all available/usable fuel mass. By contrast, in the reducing environments of charcoal kilns carbonised wood fuel is preserved almost intact with comparatively little conversion to ashes. Accurate reconstruction of ancient woodland composition can thus be obtained through the analysis of charcoals from several kiln sites within the same region, alongside the high-resolution spatial sampling of each kiln. In the case of stratified charcoal kiln deposits, detailed comparisons of the 
taxonomic spectra retrieved from different layers may also provide useful data regarding forest succession stages.

\subsection{Assessing the duration of activities from a spatial perspective: charcoal concentrations versus scatters}

Once the source of the charcoals found in an archaeological context has been established (e.g., whether they represent fuel waste debris and/or construction wood) the next crucial step involves identifying the type of charcoal deposit. This is a critical step, as it determines the purpose and intensity of sampling effort. Not all deposits carry the same potential for the purpose of palaeoenvironmental reconstruction. An essential element in this process is to evaluate the duration of activities represented in the archaeological record. As we argue below, this is a property that is independent of the density and abundance of the charred debris found in a given context/layer.

As a general rule, only the extensive spatial sampling of charcoal scatters found dispersed in an archaeological layer (usually, if not exclusively, recorded using an excavation grid) will provide a quantitatively reliable taxonomic frequency spectrum (Chabal, 1982, 1988, 1991, 1992, 1997; Badal Garcia, 1990, 1992; Heinz, 1990a, 1990b; Ntinou, 2002; Théry-Parisot et al., 2010a; Asouti and Austin, 2005; among others). As discussed at length by these authors, dispersed charcoal fragments ('charcoal scatters') are more likely to reflect lasting patterns of fuel wood use during a given phase of site occupation. Such deposits often contain a high diversity of taxa, while the taxonomic composition and taxon frequencies of the samples retrieved from the same layer are replicated across the different samples recovered from the same layer, and across contemporaneous layers. Another important point to consider here is the nature of the taphonomic filters affecting charcoal scatters. For example, trampling and weathering across the surface of a non-domestic (external) area will impact wood charcoals scattered in this layer indiscriminately and in a random (if not necessarily even) fashion. The surviving charcoal debris thus represents a random sub-sample of the remains of several episodes of fuel wood use and discard that took place during one (or more) phases of site occupation.

On the other hand, charcoal concentrations (usually associated with hearths, concentrated fuel waste deposits such as rake-outs from hearths and ovens and/or small fire pits) are all likely to represent short-lived deposits, with duration of activities ranging from a single (last) episode of hearth use to a few successive episodes of pit infilling. For this reason, 
they provide information of very limited value for reconstructing lasting patterns of fuel wood use and inferring from them past woodland composition and management, whether in a qualitative or a quantitative basis. Furthermore, the quantity of charcoal retrieved from such deposits is not a reliable indicator of the duration of the activities represented by them: thousands of charcoal fragments or none can be generated from a single, brief episode of fire use. Charcoal concentrations may be characterised by low or high taxonomic diversity, and/or be dominated by otherwise 'rare' taxa. Their taxonomic frequency spectra are thus likely to differ from those of charcoal scatters deposited in spatially extensive layers (e.g., outdoor spaces) (Chabal, 1991, 1997; Badal-Garcia, 1992). Figure 1 demonstrates an example from Taï cave (France) (Chabal and Vaschalde, in press). When a hearth charcoal sample is dominated by 1 or 2 taxa, it is not possible to determine whether they are dominant because of their abundance in the local vegetation, or because of an unknown fuel selection event controlling which taxon was used in what was essentially the last episode of hearth use.

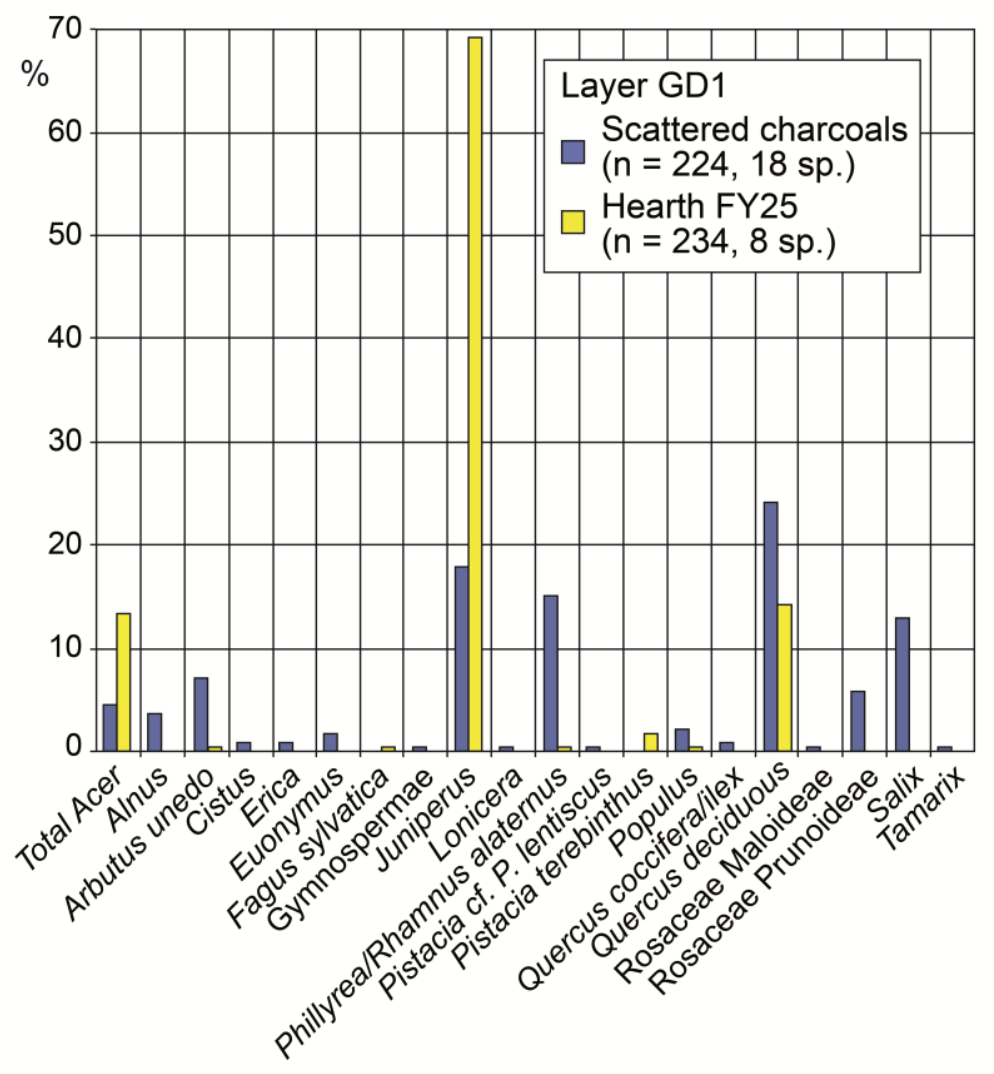

Figure 1: Hearth FY25 compared to scattered charcoal of the same layer, in the Taï cave (France) (after Chabal and Vaschalde, in press). 
For these reasons, charcoal concentrations hold very limited potential for palaeoecological interpretation. Concentrations can be studied instead for investigating possible cultural aspects of fuel uses (assuming that there exists sufficient contextual information to enable such inferences) or for assessing the probability of collection of rare taxa. They may also contain very large charcoal fragments, which provide viable specimens for dendroanthracological analyses (Ludemann and Nelle, 2002; Dufraisse, 2006, 2008; Marguerie and Hunot, 2007; Paradis, 2012; Paradis et al., 2013; Kabukcu, 2018b). Having said this, it is also necessary to note here that not all charcoal concentrations represent single and/or short-lived events. Some hearths (even those containing relatively few charcoal fragments) that could have been used over long periods of time and/or were not routinely cleaned of charred debris may contain a remarkably high diversity of taxa, including frequency spectra that are identical to those retrieved from charcoal scatters (Fig. 2) (Pernaud, 1992; Henry et al., 2013).

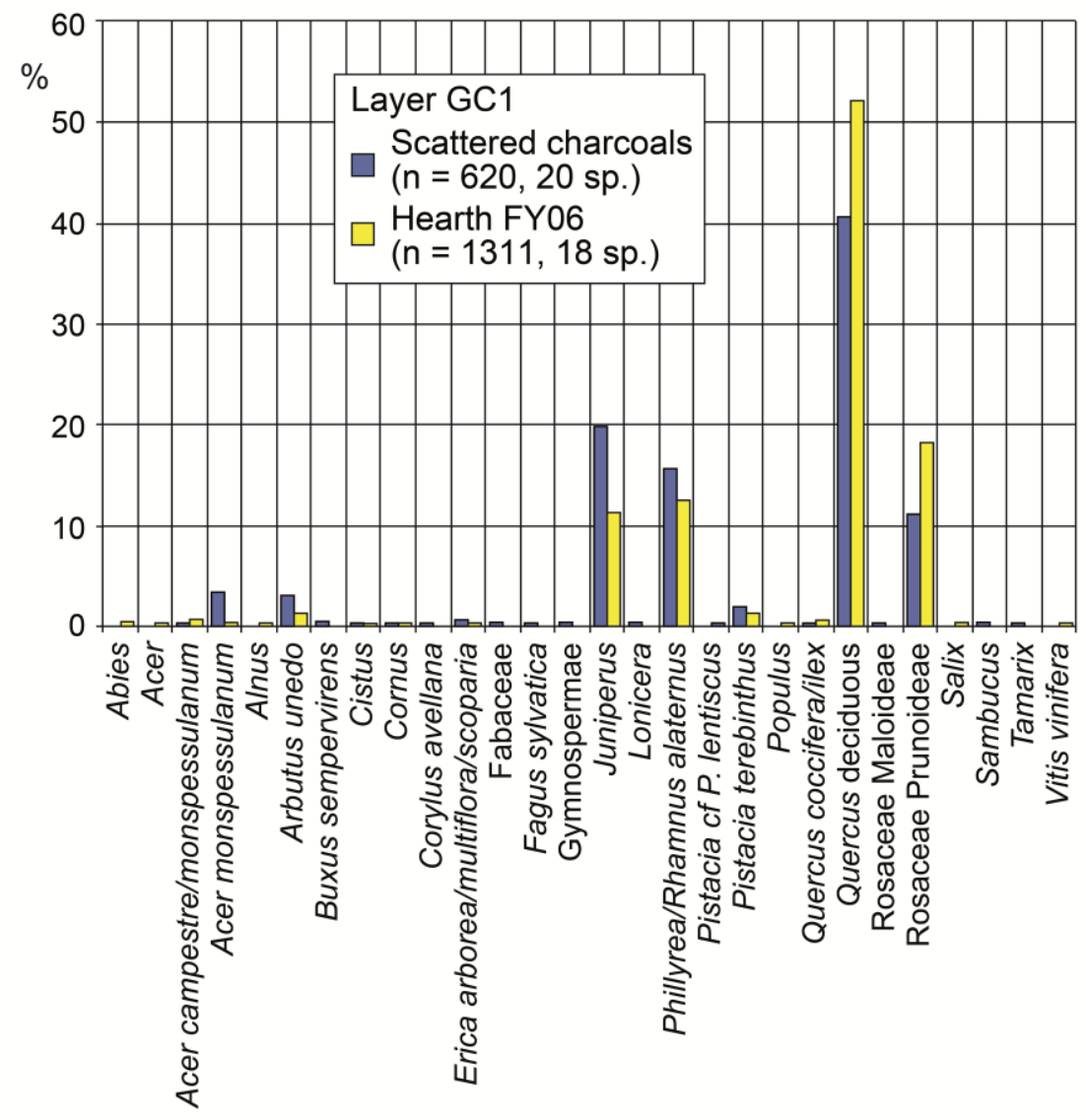

Figure 2: Hearth FY06 compared to scattered charcoal of the same layer, in the Taï cave (France) (after Chabal and Vaschalde, in press). 


\subsection{Reproducibility of the anthracological results obtained from charcoal scatters}

Assuming that sampling requirements are met, any two samples retrieved from contemporaneous levels at a given site, with the required sample size, should provide the same or closely comparable taxon frequency spectra (i.e., within a confidence interval) (Fig. 3). In other words, the relative proportions of the charcoal taxa should be reproducible across the samples derived from different layers belonging to the same stratigraphic/chronological horizon. This ensures their suitability for the purpose of palaeoenvironmental interpretation. If this condition cannot be established for samples derived from the same stratigraphic/chronological horizon then it is necessary to probe further into possible factors that may have affected taxa representation (e.g., unknown or underinvestigated context-related variation, taphonomic filters, sub-optimal sampling and recovery, etc.) During excavation, any charcoal concentration deposits within charcoal scatter layers may not be easily identified. Moreover mixing between layers and/or other stratigraphic uncertainties may also result in discrepancies in sample composition. It is thus important to detect any such heterogeneity in sample composition by spatial analysis, and to exclude (as outliers) such samples from the charcoal assemblages used for reconstructing past woodland composition and/or long-term fuel use trends.

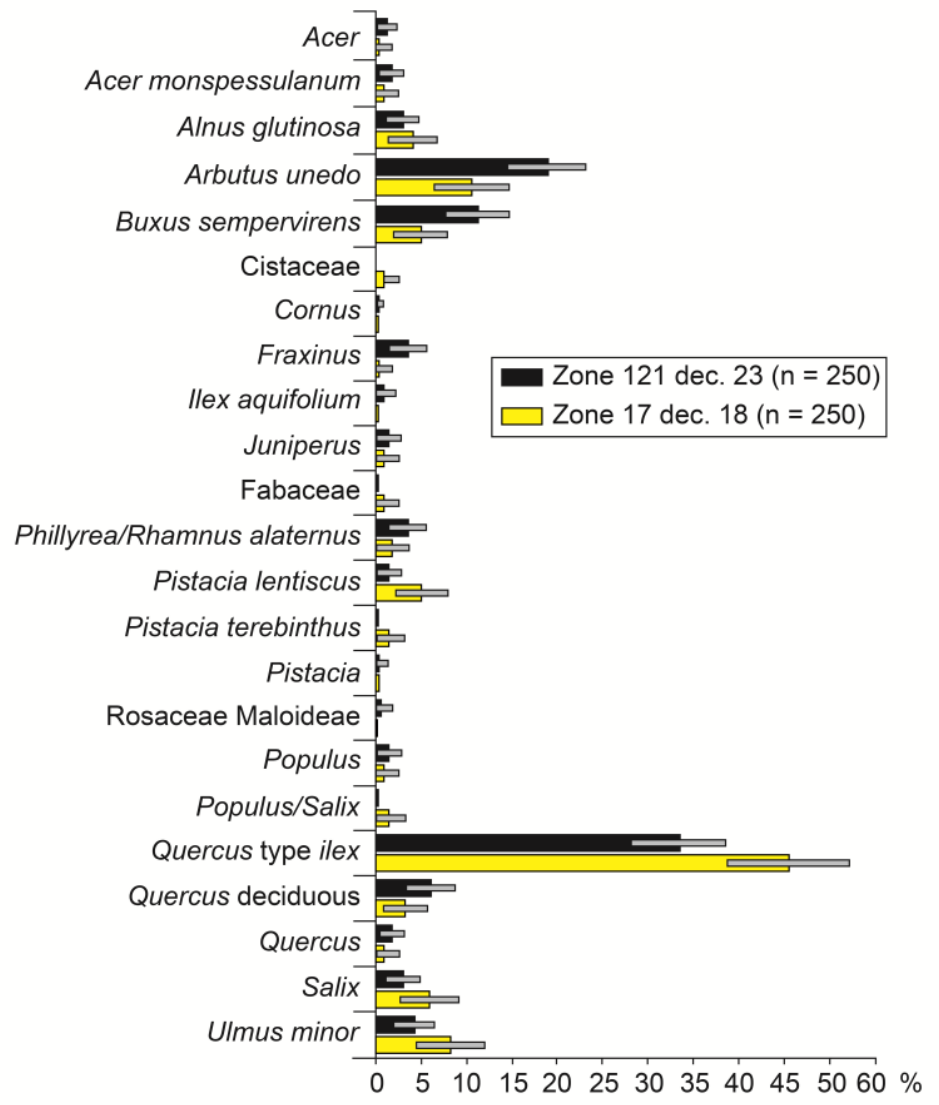

Figure 3: Taxon frequency spectra from two different synchronous houses at an Iron Age site (Le Marduel, France). The contents of the samples $(\mathrm{n}=$ 250) are almost identical (within confidence intervals), illustrating the repeatability of the measurements (after Chabal 1997). 


\subsection{The importance of sieving with respect to fragment size classes}

Among charcoal scatters, all wood charcoals, irrespective of species, fragment in such a way as to produce a high number of small fragments and a low number of large fragments; for reasons explained below, the range of fragment sizes resulting from the charcoal fragmentation process governs the selection of charcoal fragments for analysis (Chabal 1991, 1992). On first consideration, this statement may appear to contradict actualistic observations (i.e., various burning experiments testing for taxon-related differences in charcoal fragmentation). Indeed, under experimental conditions, both charcoal preservation and fragmentation tend to vary, depending on the species and burning temperatures; in some cases, it may be possible to relate fragmentation to specific wood anatomical characteristics and/or the wood density of each species (Chrzazvez et al., 2014).

However, when it comes to archaeo-anthracological assemblages, their taxonomic composition and taxon frequency spectra reflect the impacts of multiple taphonomic filters besides combustion, which have affected the preservation of fuel waste debris randomly and repeatedly over long periods of time. What the anthracologist observes is not the direct outcome of fragmentation incurred during combustion but, instead, the cumulative effects of charcoal fragmentation caused by multiple episodes of discard and burial of fuel waste debris into an archaeological layer, which are further augmented with the passage of time by postdepositional breakage due to burial and sedimentary conditions, and by sampling and retrieval methods at the point of excavation and recovery. The combined impacts of all these variables crystallise in what can be termed the 'final state of fragmentation', i.e. the observed range of fragment sizes, which is essentially independent of species (Chabal, 1982, 1990, 1992, 1997). Even during charring, temperature variations occurring within the same hearth environment (e.g., an open fire) may produce more or less resistant charcoals for any given wood species. Following this stage, and through to hearth cleaning and the disposal and burial of the fuel waste debris, most of the more fragile and/or small-sized charcoals are likely to be destroyed by repeated fragmentation episodes. The eventual distribution of the different size classes of the surviving charcoals is furthermore averaged and homogenised during the whole charcoal fragmentation process: all archaeological charcoal taxa, regardless of their original burning environments, eventually fragment in the same manner by producing a small number of large fragments and a high number of small ones.

As demonstrated in Figure 4, the range of fragment sizes in archaeological contexts closely resembles a Poisson distribution whose shape is similar for all taxa in a given sample. 
Minor variations of the Poisson distribution parameter (i.e., the mean) are observed depending on the mesh size chosen for charcoal recovery, and/or with the use of flotation recovery methods. Flotation screening, which re-fragments less charcoal than manual sieving (whether wet or dry), results in a Poisson distribution characterized by a higher mean (Chabal, 1989, 1990; Théry-Parisot et al., 2010a). They tend to have a larger spread in the size-class distribution histogram. In other words, the dominant taxa tend to produce the largest fragments in a given sample, hence a wider range of spread on the x-axis; they are also more likely to contain a higher number of small and medium sized fragments, hence a higher number on the y-axis, compared to less frequent taxa.
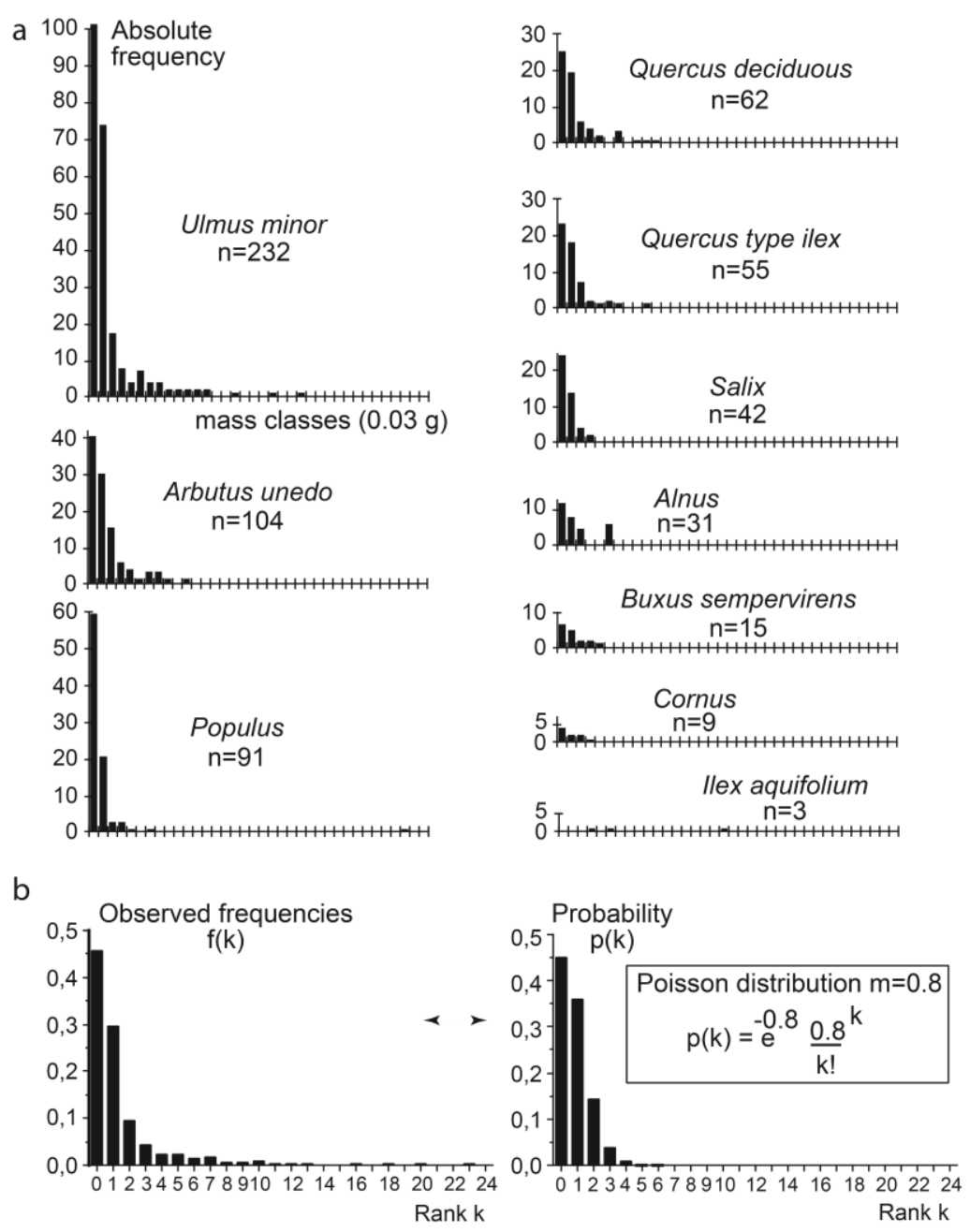

Figure 4: Charcoal fragmentation: (a) Identical mass-class frequency distributions of fragments are observed for each species in a sieved sample (here a $4 \mathrm{~mm}$ sieving on the Marduel site, layer Z11dec21A, Iron Age). (b) Taking all species together, the Poisson distribution closest to the observed distribution can be plotted (after Chabal, 1989, 1990; Théry-Parisot et al., 2010a). 
For all these reasons, it is very important to obtain a representative sample containing both large and small fragments which respects their proportions in the total sum of the fragments recovered with a given mesh size. If sampling is skewed towards the selection of the larger or the smaller fragments only, then the proportions of the charcoal taxa are likely to be biased. Generally, mesh sizes of 2, 3 or $4 \mathrm{~mm}$ are recommended for the recovery of anthracological remains, depending on charcoal preservation and density, and the time period (e.g., Palaeolithic sites in semi-arid environments may be characterised by low charcoal densities and a majority of charcoal fragments $<4 \mathrm{~mm}$, or even $<1 \mathrm{~mm}$ ). For most sites with good charcoal preservation, a $4 \mathrm{~mm}$ mesh provides excellent results relative to sampling effort, and large enough fragments to facilitate accurate microscopic identification (Chabal, 1992, 1997). Determination of appropriate sieving mesh sizes can be verified following testing for preservation of charcoal fragment size classes at each site and/or stratigraphic phase/level. In practice, especially for flotation recovery of smaller and more fragile archaeobotanical remains (e.g., small wild seeds, chaff, etc.) and rigorous retrieval of other smaller ecofacts and artefacts (e.g., microfauna, microliths, etc.) much smaller mesh sizes are necessary for both the light residue and heavy residue (e.g., 250 or $500 \mu \mathrm{m}$ ).

The choice of too large a mesh size for sampling by sieving in the field (e.g., $6 \mathrm{~mm}$ ) and, even more so, manual recovery during excavation (e.g., by hand-picking) will, without exception, favour the retrieval of only the largest fragments, which will represent only the most common taxa, thus resulting in anthracological assemblages containing few taxa. For this reason, manual recovery should be normally avoided, except in two cases: (i) for in situ preserved charcoal concentrations (e.g., from hearths) whereby hand-picking may be used for the collection of all remains visible on the ground, followed by comprehensive sediment sieving (ii) Palaeolithic sites with charcoal scatters visible during excavation (following the same procedure as for in situ charcoal concentrations).

\subsection{Sub-sampling with respect to fragment size classes}

Depending on sample size, a standardised fragment size class sub-sampling strategy may also be necessary (see 2.7 for spatial sub-sampling strategy). The only method that ensures parity in the sub-sampling of the different fragment size classes found in a given assemblage is dry sieving (or screening) of the charcoal sample in the laboratory. However, the analysis of smaller fractions is not always useful. First, fragment sizes $<2 \mathrm{~mm}$ often do not 
permit secure botanical identification. Second, small size fractions do not always enhance the palaeoecological representativeness of a charcoal assemblage, as 'rare' taxa are present in all size fractions (even $>4 \mathrm{~mm}$ mesh size). At the same time, the choice of a small size mesh (e.g., >1 mm) will necessitate the analysis of very high numbers of fragments, due to the much higher numbers of small fragments (although the proportions of the frequency of each taxon will be similar). With regard to woody shrubs (e.g., Chenopodiaceae, Compositae, woody Fabaceae, etc.) if these are routinely used as fuel (or kindling), they will be found in anthracological assemblages even in the larger-size fractions (e.g., Badal Garcia, 1990, Kabukcu, 2017) despite the fact that twigs, which burn completely and reduce to ashes due to the highly oxidising conditions of the fire, are more likely to reduce to ashes than larger calibre wood. This apparent paradox is explained by the fact that loss by burning is in fact independent of fragmentation. The surviving charcoal fragments may be large, but the taxon is likely under-represented (i.e., its proportion in the charcoal assemblage is low) (Chabal, 1992, 1997).

It is not recommended to analyse equal numbers of small, medium and large fragments, as suggested by some authors (Smart and Hoffman, 1988). This is because this would lead to the over-representation of the large fragments, and thus of the most common taxa in the assemblage. In such cases, if the frequency of a taxon is high in a stratigraphic layer (thus being over-represented by this kind of sub-sampling) and low in another layer (thus being under-represented), comparisons of frequency spectra between different stratigraphic layers are no longer feasible.

If fragment size class sub-sampling is carried out only on certain size fractions from a given sample (i.e., only from the $2-4 \mathrm{~mm}$ fraction) these results are also likely to be biased. Subsequent comparisons of their taxon frequency spectra to those contained in the $>4 \mathrm{~mm}$ fraction may also reveal differences in sample composition (and the proportions of individual taxa) (e.g., Henry et al., 2020). This is because in the 2-4 $\mathrm{mm}$ fraction the absence of fragments $>4 \mathrm{~mm}$ means that the most frequent taxa in the assemblage, which are more common in the larger size classes, will be under-represented. Comparing the taxon frequency spectra of the $2-4 \mathrm{~mm}$ fraction to the $>4 \mathrm{~mm}$ fraction will result in the selective exclusion of the dominant taxa, whereas comparing the totality of fragments $>2 \mathrm{~mm}$ to those $>4 \mathrm{~mm}$ avoids this pitfall. In other studies in which the results obtained from different size fractions have been compared (e.g., Badal-Garcia, 1990) slight differences in taxon representation do exist, but the variations in the diagram remain broadly the same taking into account either of 
the two fragment size fractions. At present, and also taking into account the observations made on the nature of charcoal fragmentation and preservation, it is advisable to focus on the $>4 \mathrm{~mm}$ or the $>2 \mathrm{~mm}$ fractions only (depending on the preservation status of the assemblage) as these are more likely to provide quantitatively robust descriptions of charcoal sample composition.

\subsection{Spatial sampling and sub-sampling strategy}

Many studies have shown that the frequency distribution of taxa in the squares of a 1x1 m excavation grid appears fairly regular between squares, if the charcoal concentrations have been excluded. Under ideal conditions, the relative frequencies of the most common taxa are normally distributed in the grid squares, which enables the study of the significance of the residual heterogeneity of a given layer (Chabal and Heinz, this issue). Theoretically, this relative homogeneity in the distribution of charcoal scatters permits obtaining representative results from sampling a few squares. However, spatially representative sampling and/or subsampling strategy is always preferable, given that: (i) spatial analysis is always of great interest, at least for retrospectively detecting concentrations or outlier squares and study the density distribution of charcoal, (ii) rare taxa seem to be distributed throughout the layers. It is likely that if we sample a large area, we will find more rare taxa. Indeed, in a very localized sampling, small charcoals are mostl likely to represent broken fragments of the larger ones. To find more taxa, more volume of sediment must be explored.

\subsection{Charcoal counts vs. weights}

Some studies have clearly demonstrated that charcoal counts and weights correlate, meaning that they may be affected to the same extent by random variance in charcoal fragmentation: the presence of some unusually large charcoal fragments and/or an excessive number of small ones (Fig. 5) (Chabal, 1982, 1990). Assuming that appropriate field sampling, screening and sub-sampling protocols are followed, both methods can produce valid quantitative descriptions of charcoal sample composition. However, since the presence of very large fragments appears as a 'rare event' of the Poisson distribution and all large fragments are usually studied, the risk of over-representing large fragments (only impacting weights) is greater compared to the risk of over-representing numerous small fragments (only impacting counts). A single very large fragment still counts as '1' fragment. Therefore, 
counting is preferable as it is far less likely to result in distortions of the taxon frequency spectra (Chabal, 1990, 1997).

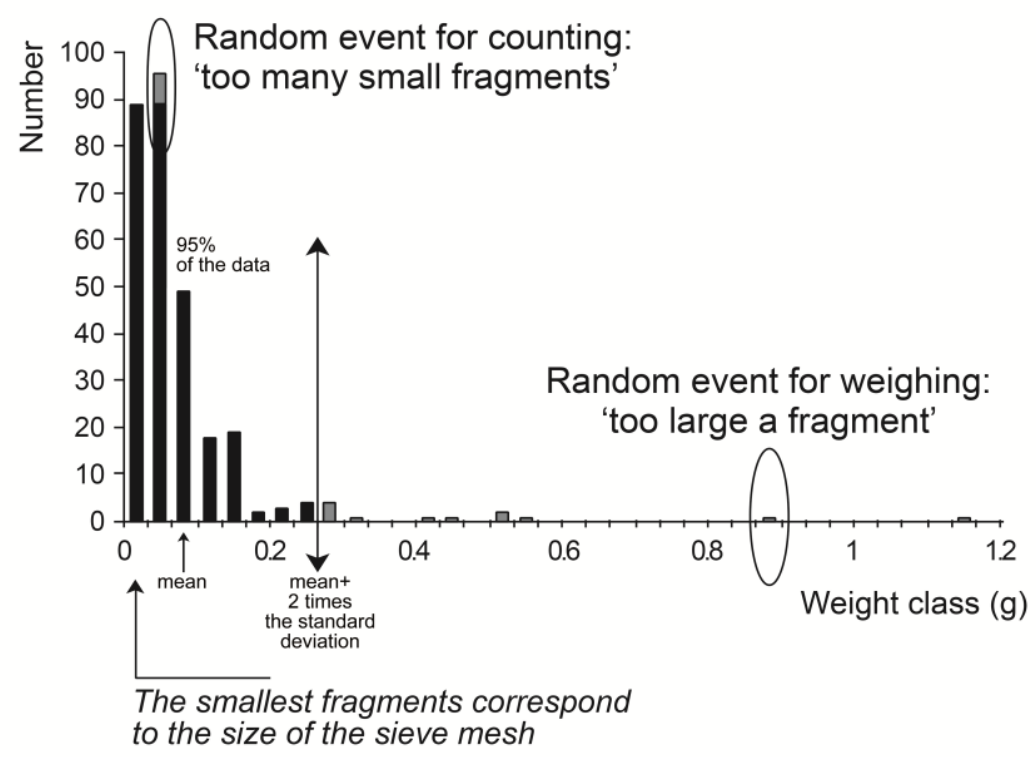

Figure 5: Counts vs weights of anthracological remains: according to the Poisson distribution (here a sample from the Lattara site, obtained by flotation), counting or weighing charcoals are two equally valid methods, due to the distributions being affected by symmetrical rare events. Since large fragments (only impacting weights), are systematically studied, counting is less likely to distort the frequencies of taxa.

\subsection{Sample size: the meaning of accumulation curves}

Taxon accumulation curves are used to determine optimal sub-sample size, provided all other methodological prerequisites (see previous sections) are met. They should not be confused with saturation curves, used in ecology, which are created by randomly re-sampling the pool of $\mathrm{N}$ samples multiple times and then plotting the average number of species found in each sample. An accumulation curve is a graph that plots the rank of the newly identified taxa (the cumulative number of taxa) against the rank of the analysed fragments (the cumulative number of fragments) in order of identification. Indeterminate fragments (or taxa that clearly overlap with the list of identified taxa, such as Angiospermae and some 'cf.' identifications of the same taxa) should not be plotted in the accumulation curve as they do not represent a 'new' taxonomic identification.

The accumulation curve increases rapidly at first, as the most frequent taxa are encountered and eventually reaches a plateau when only the rarest charcoal taxa remain. The plateau does not have a mathematically defined end point, only an estimated one (Godron, 
2012, Vol. 2, p. 226; Gotelli and Colwell, 2011). As a general rule, it is recommended to study a minimum of 250 fragments per stratigraphic layer/phase (Chabal, 1982, 1988, 1992, 1997). 250-400 charcoal fragments per layer/phase represent in most cases an optimal sample (Fig. 6a). Phases/strata with very few identified charcoal specimens (e.g., <80) should be interpreted with extreme caution. If this low number of identifications is due to poor charcoal preservation (e.g., very small fragments, over-abundance of vitrified specimens, or generally low numbers of charcoal fragments) these issues can be addressed by increasing the volume and/or the number of samples collected in the field. In all cases, it is best to include either confidence intervals on the anthracological diagram and/or clearly indicate on it the numbers of identified specimens (NISPs) from each sample, in order to enable a thorough evaluation of the assemblage by other anthracologists and facilitate future meta-analyses of the datasets.

A prerequisite for the correct application of taxon accumulation curves is that the studied charcoal sample represents a random selection of the charcoal population contained in each sampled layer/stratum. If charcoals are sampled from different squares within the same layer and analysed in the lab one after the other, then the per square accumulation curves will only capture the heterogeneity of charcoal sample composition across the sampled layer/stratum: the curve would increase in a step-like manner (Fig. 6b). This type of accumulation curve represents a species-area curve. Species-area curves may or may not be smooth with regard to the homogeneity of the charcoal scatters, but in all cases, they tend to be less smooth than accumulation curves obtained from the per phase/stratum charcoal populations. Nevertheless, assuming that per square sampling has occurred, samples originating from different squares should not be mixed together in order to obtain a smooth accumulation curve. Doing so would result in loss of information regarding spatial variation and heterogeneity in taxon representation, which are just as interesting vis a vis palaeoecological analysis as are the taxonomic frequency spectra derived from individual phases/strata (Chabal and Heinz, this issue). 
a

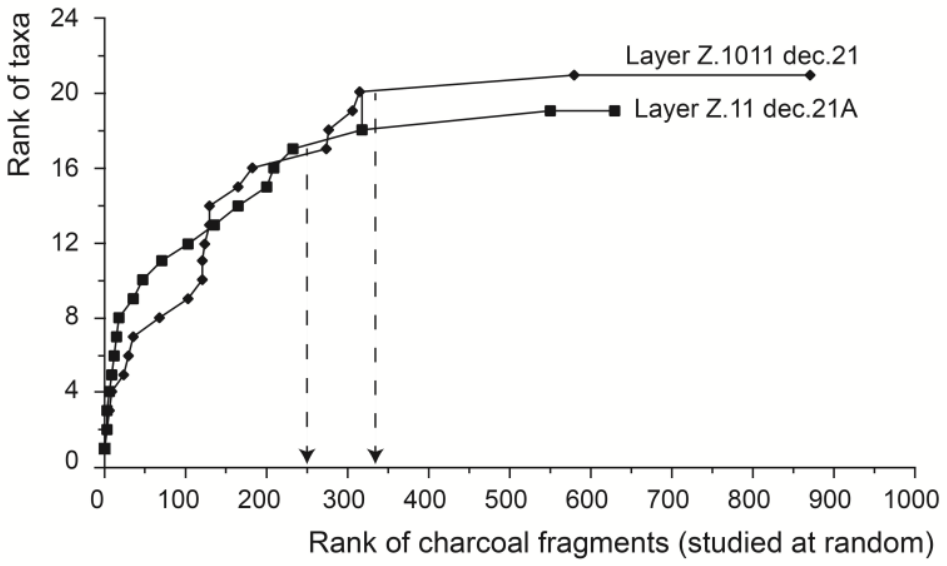

b

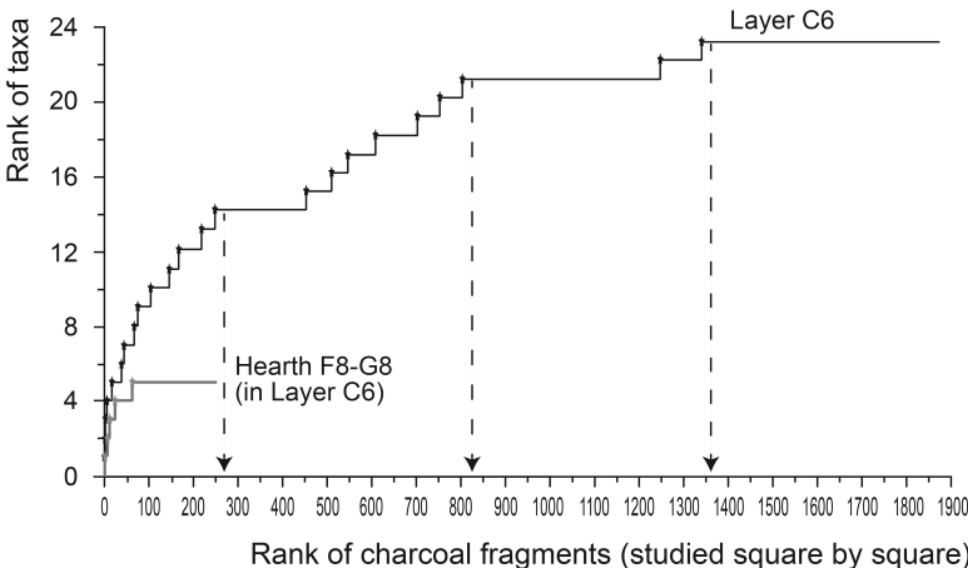

C

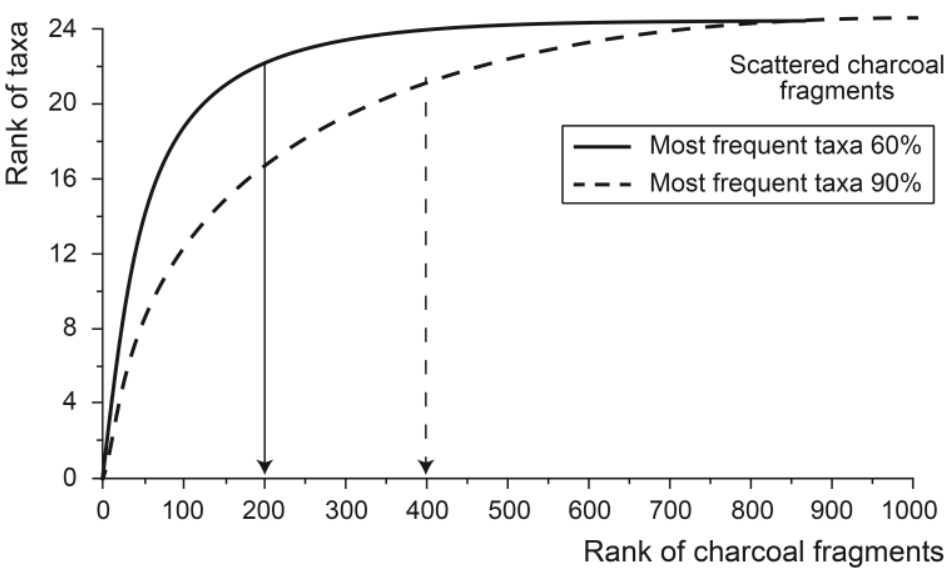

Figure 6: Sub-sample size: (a) Accumulation curves related to scattered charcoals studied at random in two layers at the Marduel site, Iron Age, France (after Chabal, 1997): the plateau is about 250-350 fragments. (b) Speciesarea curve related to scattered charcoals (and a hearth) studied square by square $\left(11 \mathrm{~m}^{2}\right)$ in one layer in the Abeurador cave, Mesolithic, France (after Heinz, 1990b): the curve increases in steps, reflecting the slight heterogeneity of the layer. (c) Theoretical accumulation curves: the slope and plateau of the curve depend exclusively on the frequencies of the main taxa, and not on the diversity (total number of taxa).

Accumulation curves were initially deployed to maximise the likelihood of recording all taxa present in an archaeological charcoal assemblage. The rise of the curve and the number of fragments required for it to level-off depend exclusively on the rate of occurrence of the most abundant taxa in a given sample, not on the total number of taxa found in it (e.g., the curve may stabilize at 20 taxa for 150 fragments, or 10 taxa for 300 fragments). The curve rises faster (solid line in Fig. 6c) if the most abundant taxa register relatively low counts in a given sample. For example, if 2 or 3 frequent taxa account for $60 \%$ of the charcoal sample 
composition, rare taxa would account for the remaining $40 \%$ and are likely to appear during the earlier stages of identification work on the sample. As a result, the accumulation curve of such a sample would reflect a sharp increase. The increase of the accumulation curve on the $y$-axis is more gradual (dashed line in Fig. 6c) if the most frequent taxa account for $90 \%$ of sample composition, in which case rare taxa are less likely to be identified earlier in the analysis of a given sample. As a result, deciding on the optimal sample size with regard to the levelling-off point of an accumulation curve is a function of the relative abundance (i.e., \% proportion of fragment counts) of the most abundant taxa in a sample (Chabal, 1997). It is therefore advisable to construct a few accumulation curves for a given site, in order to determine optimal sub-sample sizes and cut-off points for charcoal identification work. But it is not necessary to construct accumulation curves for each analysed sample, because for assemblage as a whole the optimal number of fragments will vary very little. Accumulation curves are a practical means for predicting minimum sub-sample size. However, since the order of study of the sample fragments may influence the rise of the curve (e.g., when large fragments studied before the small ones), the curve may reach the plateau later, thus it is advisable to study a slightly higher number of fragments than indicated.

As a general rule, in mature forests of western temperate regions $\sim 20 \%$ of the woodland taxa constitute $\sim 80 \%$ of the biomass and this ratio is also reflected in the charcoal taxon counts in archaeological assemblages, which is one of the arguments in favour of the palaeoecological representativeness of the assemblages (Chabal, 1992, 1997). A total number of ca. 250-400 identified fragments per stratum/layer is a good sampling target for such an assemblage. In tropical contexts, anthracological assemblages often display much higher diversity and the corresponding accumulation curves reach a plateau more rapidly. In such cases, fewer identified fragments, for example 200-300, are likely to represent a sufficient sample size (Scheel-Ybert 1998, 2002).

\section{From fuel wood to palaeoenvironmental interpretation}

\subsection{The burning properties of wood with regard to wood collection and combustion}

The burning properties and calorific values of wood species condition both wood collection and use (i.e., the concepts of 'good' vs. 'bad' fuel) and the effects of combustion on wood (mass loss and taxa proportions). Both relate to the interpretation of anthracological 
data and have been much debated topics in anthracology (Rossen and Olson, 1985; Chabal 1997, 2001; Théry-Parisot, 2001; Théry-Parisot, 2010a, 2010b; Henry, 2011; references therein).

The 'Lower Calorific Value' (LCV) or 'net calorific value' of wood (expressed at 12\% moisture content, which is seen as very dry wood) represents the amount of heat emitted in relation to wood mass and is expressed in kcal (or $\mathrm{J}$ ) per $\mathrm{kg}$ of wood. LCV varies very little by species with maximum differences of $800 \mathrm{kcal} / \mathrm{kg}$ (Fig. 7) and does not approximate the energy returns of coal, charcoal burnt as fuel, or oil (Briane and Doat, 1985; Chabal and Laubenheimer, 1994; Théry-Parisot, 2001). According to Enes et al. (2019) conifers have generally higher LCVs than hardwoods, although these authors also recognize that differences between hardwoods and softwoods may relate more to the presence of resins and other chemical substances than to net lignin content; some resin-rich conifers and Olea wood have a slightly higher calorific value. LCV value is not directly related to wood density: taxa such as Alnus (a low-density wood) have a slightly higher calorific value than Quercus ilex (a highdensity wood), which in turn has a higher calorific compared to Populus (a low-density wood) (Fig. 7).

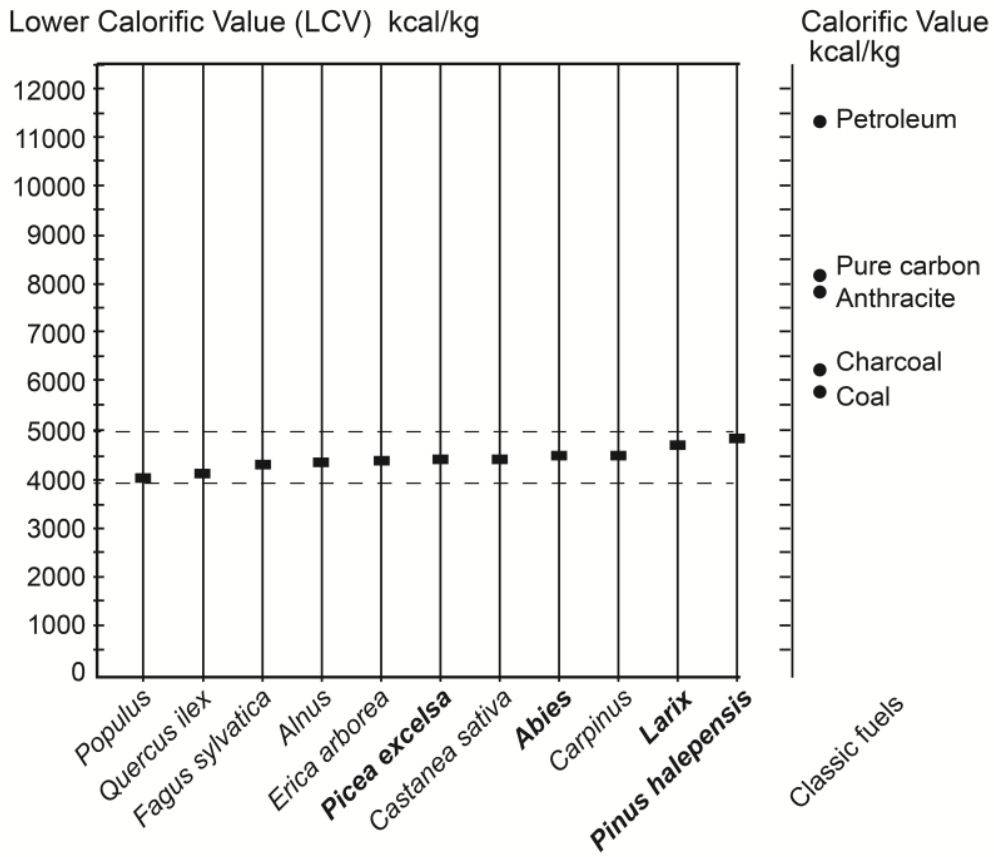

Figure 7: Fuelwood heat generation properties: the Lower Calorific Value (LCV), defined for wood at $12 \%$ moisture content, varies very little by species and does not correlate with wood density; in bold, conifers (after Briane \& Doat, 1985; Chabal and Laubenheimer, 1994; Théry-Parisot, 2001). 
The persistent misconception of a relationship between species and calorific value owes its existence to the fact that calorific value is defined per $\mathrm{kg}$. When an oak log and an alder log of the same size are burnt, the oak log that is three times heavier than alder will produce three times more heat than alder. However, if $1 \mathrm{~kg}$ of oak and $1 \mathrm{~kg}$ of alder are burnt, there will be no perceptible difference in their respective energy returns. It follows that perceived differences in the heat-related burning qualities of different species do not correspond to empirical data in relation to heat generation. Thus anthracological interpretations suggesting that such criteria might have applied to past perceptions of the burning properties of different wood species are not grounded on scientific evidence. Culturally defined differences in burning properties might or might not have applied in the past.

LCVs depend primarily on the 'condition' of the wood used as fuel. The calorific value of all wood species increases as moisture content decreases (Fig. 8) (Briane and Doat, 1985; Chabal and Laubenheimer, 1994; Théry-Parisot, 2001). For example, the calorific value of wood left to dry for 20 months under cover (20\% moisture content) is $4200 \mathrm{kcal} / \mathrm{kg}$. The moisture content of the same species in green form (i.e., as freshly cut unseasoned wood) is $80 \%$ with a considerably lower calorific value at $\sim 700 \mathrm{kcal} / \mathrm{kg}$. Calorific value also varies according to the physiological status of wood (i.e., solid versus dead/decaying wood) (ThéryParisot, 2001). It is obvious that when it comes to these two key properties (moisture content and the condition of wood) any (perceived) differences in energy returns between species are, as a matter of fact, irrelevant.

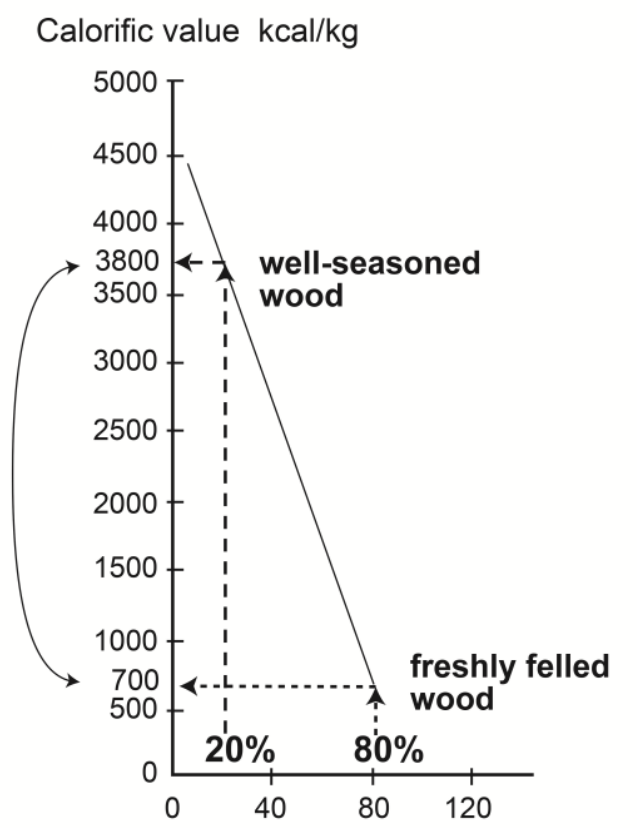

Figure 8: Fuelwood heat generation properties: the calorific value of a given species varies considerably as a function of the moisture content of the wood, much noticeably than the differences between species (after Briane and Doat, 1985; Chabal and Laubenheimer, 1994; ThéryParisot, 2001).

Wood moisture content as $\%$ of total weight 
Other important burning properties are flame height, speed and duration of wood combustion, which vary depending on wood density. Low-density woods tend to burn quickly with high flames, while high-density woods burn with short flames and for longer periods of time. However, these properties are significantly altered once wood calibre is taken into account (Fig. 9). Small stems and split logs burn rapidly even for species characterised by high wood densities (Chabal, 1997; Bourquin-Mignot et al., 1999; Théry-Parisot, 2001; Théry-Parisot et al., 2010a). Hearth structure and architecture also exert significant impacts on burning properties; oxygen flow in a fire (and thus burning speed) is, to an extent, a function of the structural porosity of wood although, in this case too, the impact of using split $\log$ and/or small-diameter stems will also affect the burning efficiency of fires.

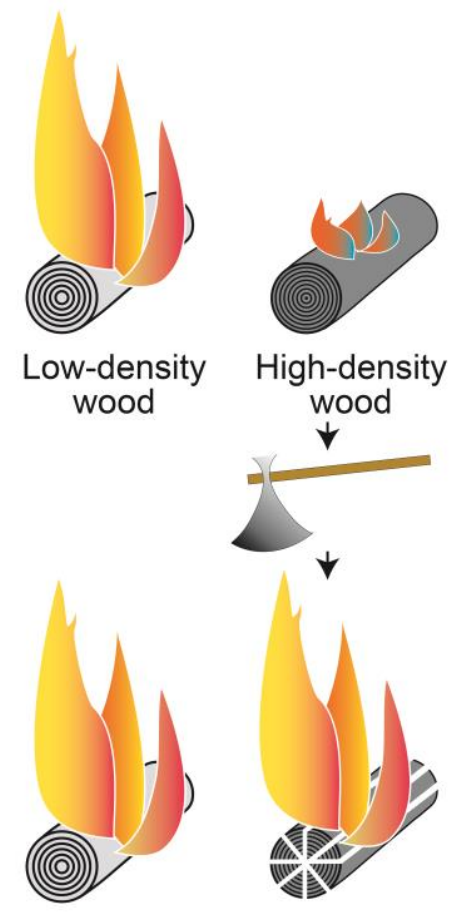

The effect of combustion on mass loss and taxon proportions has been studied through experiments. Théry-Parisot et al. (2010b) carried out standardized single-species burning experiments in open fireplaces. These authors demonstrated that multiple parameters influence the amount of charcoal remaining after combustion, with some unaccounted degree of variability. A residue rate correlated to certain species groups does exist, but it can also vary with the collection location (woodland catchment), and therefore the impact of species is not clearly supported. Wood density, anatomical structure, moisture content, burning temperatures reached or fire duration were not significant factors in mass loss. The results of monospecific burning events were amalgamated by the authors, to propose a theoretical

Figure 9: Fuelwood properties: flame length, speed and duration of combustion depend on the density of the wood, but are strongly affected by the size of logs and wood calibre (after Chabal, 2001; Théry-Parisot, 2001; Théry-Parisot et al., 2010a). 
correlation between taxa originally burnt and the residual charcoal. This work has demonstrated that the proportions of the species after burning reflect with a good degree of accuracy their proportions before burning, with no inversion of the highest and lowest frequencies (Théry-Parisot et al., 2010b, Fig. 14).

\subsection{Palaeoecological interpretation of anthracological datasets}

As discussed above, the heat-generating properties of wood species are unlikely to have been a limiting factor in fuelwood collection and use. Other factors such as moisture content, resin/oil content, wood condition (e.g., deadwood, greenwood), log calibre and other pyrotechnological variables have a much greater impact on fuel wood collection. In most cases, the fuel wood species present in the environs of a given habitation site are used in proportion to their distribution and abundance in the local landscape. In turn, both abundance and distribution are not fixed properties in time and space, but vary depending on ecological (climate change, disturbance, etc.) as well as human-imposed (e.g., woodland management) constraints. Additionally, various socio-economic and cultural factors can contribute to woodland use, beyond parameters involved in fuel wood procurement. Research on ethnographic, ethnoarchaeological and theoretical aspects of woodland use practices and the question of fuel selection beyond properties linked to pyrology and/or environmental availability addresses some of these complex issues in greater detail (Dufraisse et al., 2007; Henry, 2011; Picornell-Gelabert et al., 2011; Delhon, 2018; Picornell-Gelabert, 2020). Stochastic processes including fuel wood collection, burning, the cleaning and discard of fuel debris, and post-depositional processes also contribute to the formation of the anthracological assemblage, which represents a palimpsest of various types of palaeoecological information. It is thus argued that the range and proportions of wood taxa found in anthracological assemblages represent a reliable proxy of past woodland composition. At the same time, however, any and all palaeoecological interpretations of anthracological assemblages rely on the proper application of the methodological principles described and discussed in the previous sections, including the selection of appropriate archaeological contexts for study, rigorous on-site and laboratory analytical procedures, and quantification (i.e., data recording) protocols and finally a close inspection of the sample-by-sample data for determining the palaeoecological representativeness of the datasets.

In this regard, multivariate analyses of wood charcoal counts from charcoal scatters offer distinctive advantages for the palaeoecological interpretation of anthracological datasets. 
For example, in situations where datasets from multiple sites are available multivariate techniques such as Correspondence Analysis (CA) facilitate the examination of a large number of samples across different time periods, thus enabling the detection of distinct 'micro-ecologies' at each site and/or for different phases of occupation in a given region. The application of CA on a moderately large anthracological dataset from four different prehistoric habitation sites in south-central Anatolia (Turkey), spanning approximately nine millennia from the Lateglacial to the mid-Holocene (Kabukcu, 2017) exemplifies how the challenges presented by anthracological assemblages derived from different habitation sites covering long periods of time, can be overcome with multivariate evaluations in a way that is not easily achievable by charcoal diagrams.

When a charcoal diagram is used as the basis for the palaeoecological interpretation of the Anatolian assemblage (Fig. 10a) the anthracological datasets from the sites of Boncuklu, Can Hasan III and Çatalhöyük form parts of a fragmented sequence with very little commonality observed between sites in terms of charcoal assemblage composition (a point further exemplified by the radically different nature of the Pınarbaşı charcoal assemblage that required the construction of an additional diagram; Fig. 10b). This is the case despite the fact that all four sites were located in the same landscape (the high-altitude intramontane plateau of the Konya plain) and at relatively short distances from each other. Additional challenges were presented by the chronological complexities of the regional sequence. Non-contiguous occupation phases at Pınarbaşı partly overlapped with aceramic Neolithic occupations at Boncuklu as well as ceramic Neolithic and Chalcolithic occupations at Çatalhöyük. In addition, intrasite archaeological phasing and radiocarbon chronologies did not represent equal time slices that could enable linking across time the charcoal assemblages from each site. These issues were compounded by the clear differences observed in assemblage composition, diversity and taxon frequency spectra between all sites, which indicated the existence of a highly fragmented mosaic of local woodland habitats. This phenomenon is not restricted to central Anatolia but has been widely observed in other semi-arid regions of the Middle East, whereby sites located in close proximity to each other are often characterised by widely different anthracological spectra. In order to overcome these issues, Kabukcu (2017) applied CA on the per-sample fragment counts of all charcoal scatter samples available from each site (instead of grouping such samples by site phase, which is the norm with anthracological diagrams) (Fig. 11). In terms of evaluating temporal patterning, the CA biplot more accurately represents the chronological sequencing between the sites, clustering the contemporaneous phases at Boncuklu with those at Çatalhöyük, driven predominantly by 
variability in the appearance of deciduous oak charcoal, representing a period coinciding with the establishment of deciduous oak in the regional woodlands as indicated by palynological analyses and species distribution modelling (Asouti and Kabukcu, 2014, Kabukcu, 2017,

Collins et al., 2018). This dual approach to the dataset from central Anatolia enabled detecting both long-term shifts in regional woodland composition (e.g., the development of semi-arid deciduous oak and juniper woodlands) as well as more localised woodland habitats such as the Salicaceae-dominated riparian and wetland woodlands. CA and other multivariate analyses thus present particularly powerful tools for mapping the diachronic development of complex woodland catchments that were not limited to a single ecotone and/or were uniformly distributed across the landscape. In other cases, multivariate techniques can be used for integrating different archaeobotanical datasets (anthracological and non-wood macrofossils) thus enabling multi-proxy palaeovegetation reconstructions (e.g., Asouti et al., 2015, 2018, 2020; Martínez-Varea et al., 2019; among others).

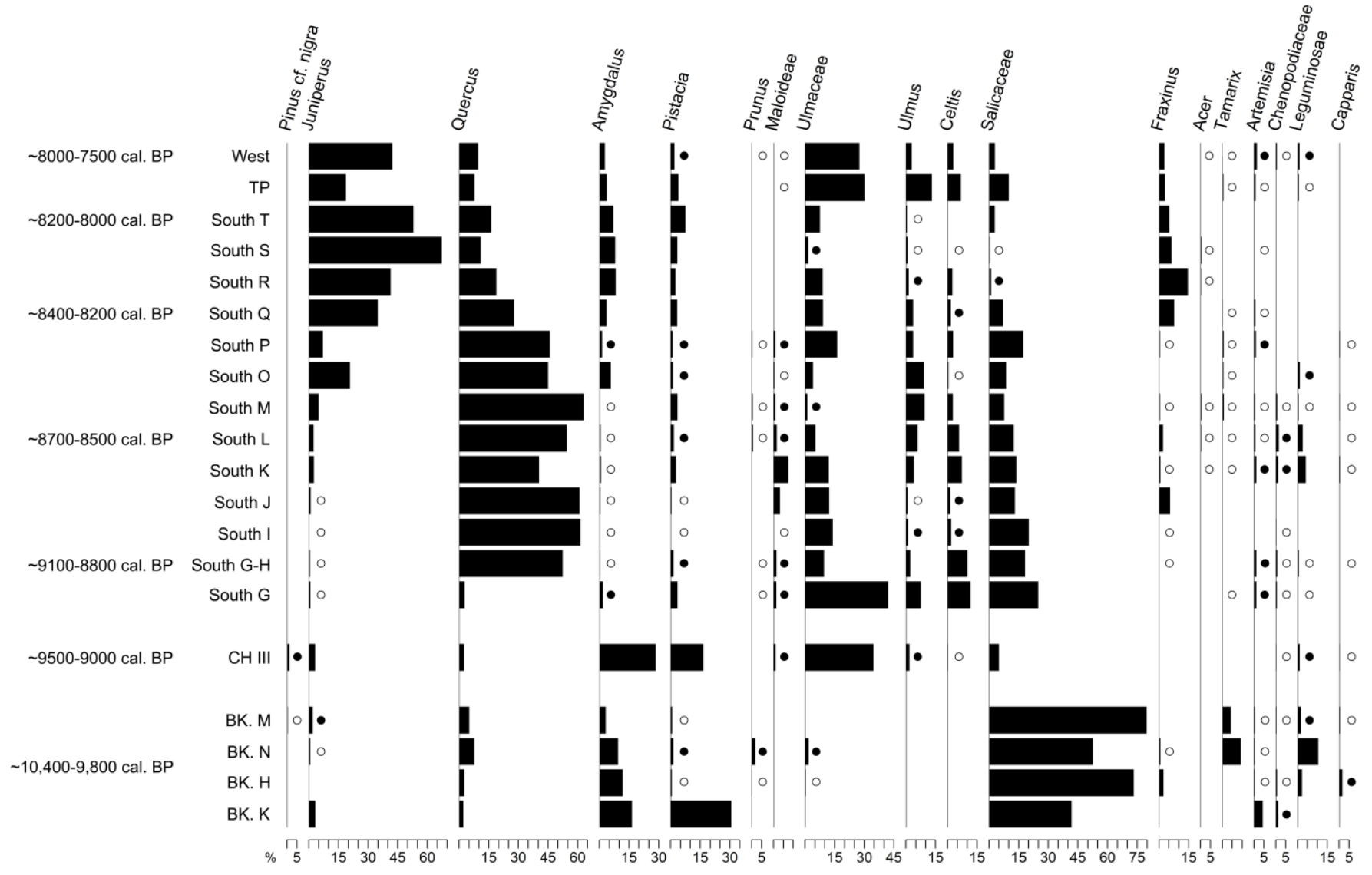

Figure 10a: Anthracological diagram from all sampled phases at Boncuklu, Can Hasan III and Çatalhöyük East and West mounds (charcoal scatter contexts) (dark dots represent fragment counts $<2 \%$, white circles fragment counts $<1 \%$ ). For full dataset, see Kabukcu 2017 (modified after Kabukcu 2017:Figure 4). 


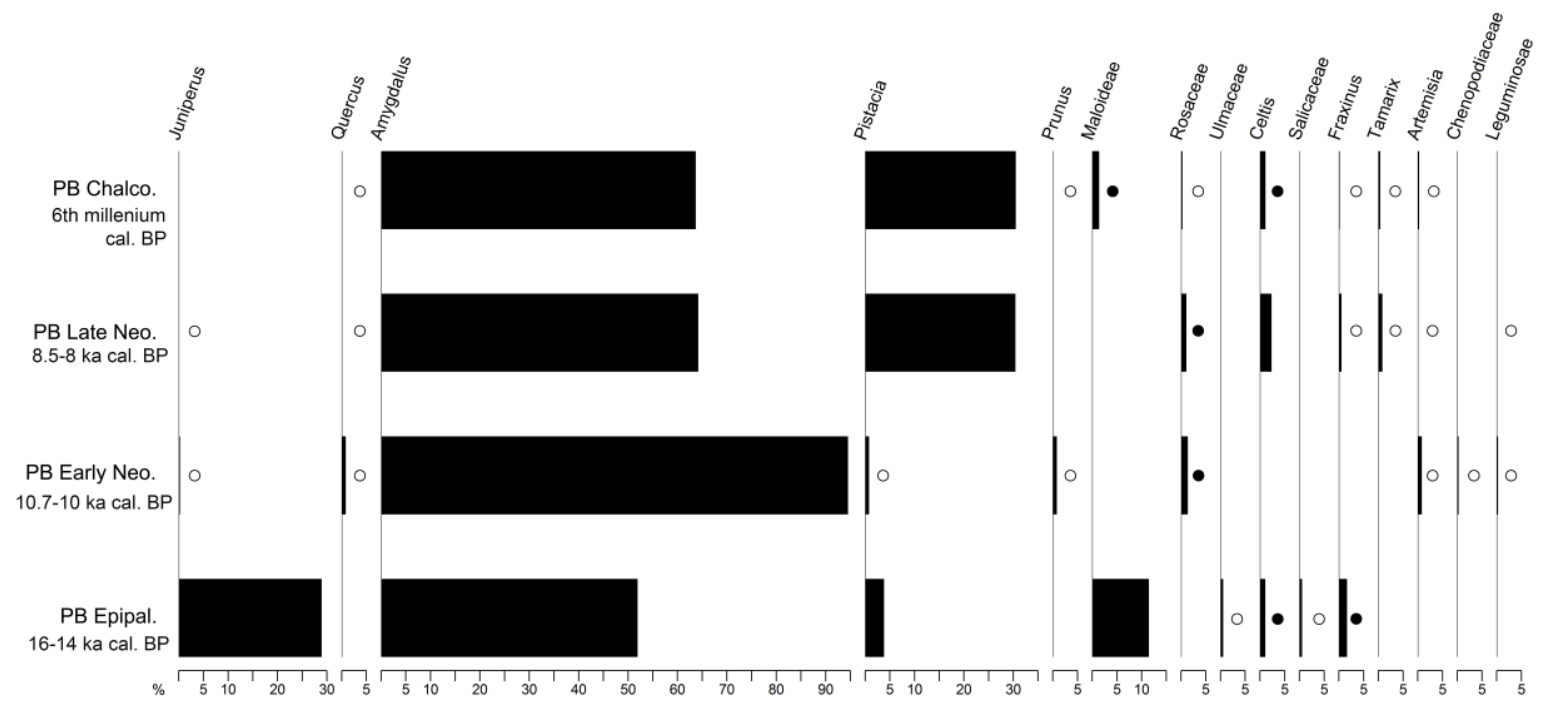

Figure 10b: Anthracological diagram from all sampled phases at Pınarbaş1 (charcoal scatter contexts) (dark dots represent fragment counts $<2 \%$, white circles fragment counts $<1 \%$ ). For full dataset, see Kabukcu 2017 (modified after Kabukcu 2017:Figure 3).

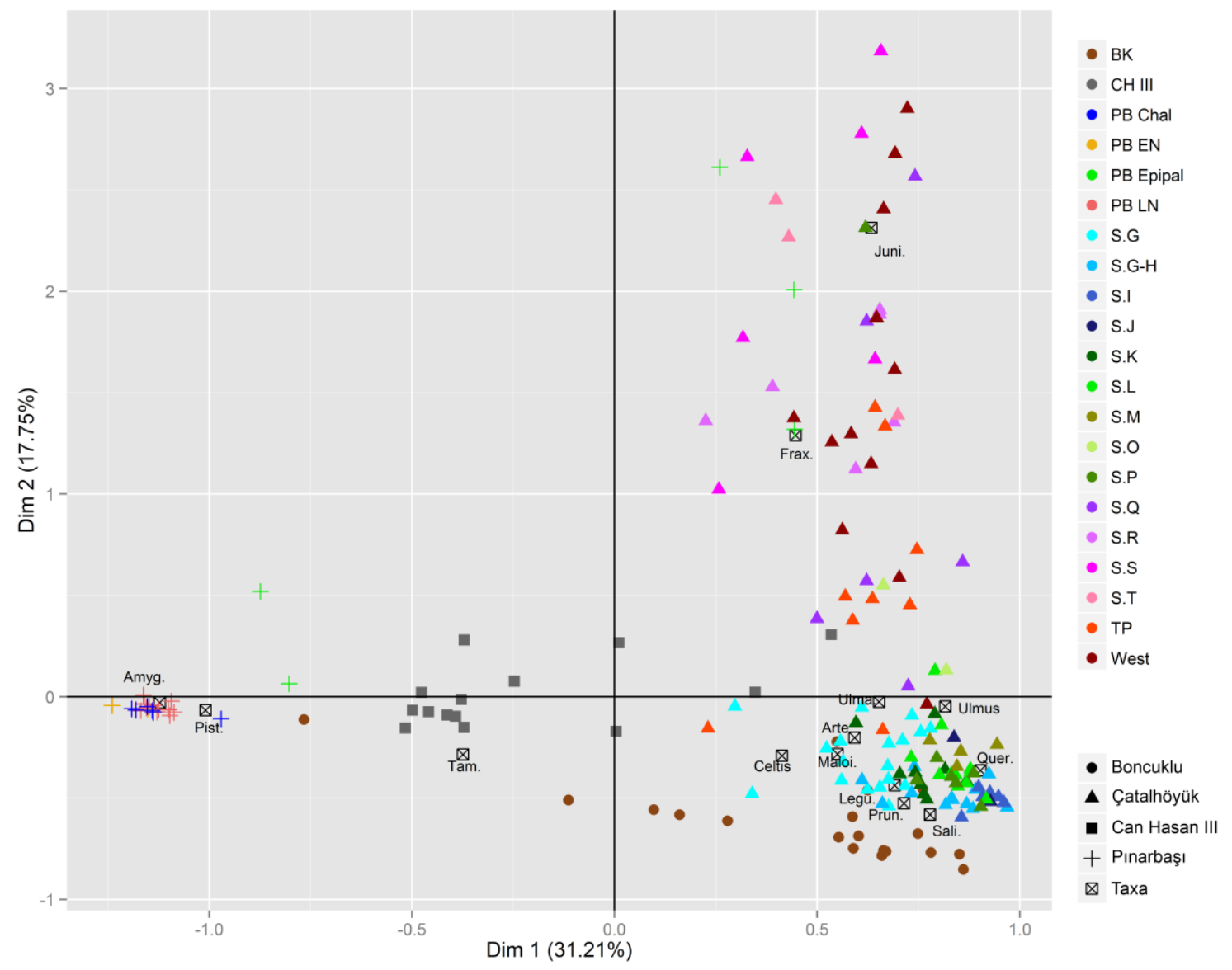

Figure 11: Correspondence Analysis biplot, run on per sample wood charcoal taxon counts (charcoal scatter contexts only) from all sampled phases at Pınarbaşı, Boncuklu, Can Hasan III and Çatalhöyük East and West mounds. For full dataset and results see Kabukcu 2017 (modified after Kabukcu 2017: Figure 5). 


\section{Conclusion}

Our discussion of the key methodological principles of anthracology demonstrates clearly that anthracological assemblages sourced from fuel waste deposits accumulated in the long-term, represent an accurate reflection of the relative proportions of the taxa used as fuel wood in the past, provided that the appropriate context selection, sampling, sub-sampling and quantification methods are observed. The palaeoecological representativeness of anthracological data may not always be 'precise' due in large part to the various taphonomic filters impacting the preservation of charcoal macro-remains. Nevertheless, the replicability of results across different strata/phases of occupation at most sites demonstrates the utility of anthracological data for reconstructing past woodland composition and use.

Furthermore, even if there are cases to be made with regard to fuel selection (e.g., on the basis of deadwood availability and productivity, and actual or perceived differences in burning properties related to the condition of wood and pyrotechnologies), these do not limit the value of anthracological data as palaeoecological proxies. In many parts of the world, some of the most important pioneer species in regional woodlands are either sporadic/low pollen producers and/or insect-pollinated species (e.g., Rosaceae, Juniperus, Pistacia, etc.) (Auro et al., 2005; Baird et al. 2013; Ntinou and Kyparissi-Apostolika, 2016; Kabukcu, 2017; Asouti et al., 2018; among others). Anthracology provides one of the most complete proxies for understanding critical periods of vegetation and associated climate change, as well as the long-term evolution of local and regional vegetation histories, from the late Pleistocene through to the historical periods, especially in conjunction with the study of other palaeoecological proxies. (Nelle et al., 2010; Roberts et al., 2018). As the discipline develops in analytical capacity and scope with the increasing application of methodological tools for exploring woodland management through dendro-anthracology and palaeoclimates through charcoal stable isotope analyses, its palaeoecological potential will continue to increase.

\section{Acknowledgements}

Ceren Kabukcu's research is supported by a Leverhulme Trust Early Career Fellowship (grant no. ECF-2017-284). The authors would like to thank the two anonymous reviewers for their insightful comments and constructive feedback. 


\section{References}

Asouti, E., 2002. Charcoal analysis from Çatalhöyük and Pınarbaşı, two Neolithic sites in the Konya plain, south-central Anatolia, Turkey. Ph.D. Thesis, University College London.

Asouti, E., Austin, P., 2005. Reconstructing Woodland Vegetation and its Exploitation by Past Societies, based on the Analysis and Interpretation of Archaeological Wood Charcoal Macro-Remains. Environmental Archaeology. 10: 1-18.

Asouti, E., Baird, D., Kabukcu, C., Swinson, K., Martin, L., García-Suárez, A., Jenkins, E. and Rasheed, K., 2020. The Zagros Epipalaeolithic revisited: New excavations and 14C dates from Palegawra cave in Iraqi Kurdistan. PLoS One, 15(9), p.e0239564.

Asouti, E., Kabukcu, C., 2014. Holocene semi-arid oak woodlands in the Irano-Anatolian region of Southwest Asia: natural or anthropogenic? Quaternary Science Reviews 90: 158182.

Asouti, E., Kabukcu, C., White, C.E., Kuijt, I., Finlayson, B. and Makarewicz, C., 2015. Early Holocene woodland vegetation and human impacts in the arid zone of the southern Levant. The Holocene, 25(10): 1565-1580.

Asouti E., Ntinou M., Kabukcu C., 2018. The impact of environmental change on Palaeolithic and Mesolithic plant use and the transition to agriculture at Franchthi Cave, Greece. PLoS ONE 13 (11), p.e0207805.

Aura, J., Carrión, Y., Estrelles, E., Jordà, G., 2005. Plant economy of hunter-gatherer groups at the end of the last Ice Age: Plant macroremains from the cave of Santa Maira (Alacant, Spain) ca. 12000 - 9000 B.P. Vegetation History and Archaeobotany, 14(4): 542-550.

Badal Garcia, E., 1990. Méthode de prélèvement et paléoécologie du Néolithique d'après les charbons de bois de la Cova de les Cendres (Alicante Espagne), in: Hackens, T., Munaut, A.V., Till, Cl. (Eds.), Wood and Archaeology. Bois et archéologie. First European Conference, Louvain-la-Neuve, Belgique, Oct. 2nd-3rd 1987. PACT. 22, pp. 231-224.

Badal Garcia, E., 1992. L'anthracologie préhistorique : à propos de certains problèmes méthodologiques, in: Vernet, J.-L. (Ed.), Les charbons de bois, les anciens écosystèmes et le rôle de l'Homme, Colloque International de Montpellier, 10-13 sept. 1991, Bull. de la Société botanique de France, Actualités Botaniques. 139 (2/3/4), pp. 167-189.

Badal Garcia, E., Carrión, Y., Macías, M., Ntinou, M. (Eds.) 2012. Wood and charcoal: Evidence for human and natural history. Sagvntvm Extra. 13: 1-299.

Baird, D., Asouti, E., Astruc, L., Baysal, A., Baysal, E., Carruthers, D., Fairbairn, A., Kabukcu, C., Jenkins, E., Lorentz, K., Middleton, C., 2013. Juniper smoke, skulls and wolves' tails. The Epipalaeolithic of the Anatolian plateau in its South-west Asian context; insights from Pınarbaşı. Levant, 45(2): 175-209. 
Baird, D., Fairbairn, A., Jenkins, E., Martin, L., Middleton, C., Pearson, J., Asouti, E., Edwards, Y., Kabukcu, C., Mustafaoğlu, G., Russell, N., 2018. Agricultural origins on the Anatolian plateau. Proceedings of the National Academy of Sciences, 115(14): E3077-E3086.

Bonhôte, J., Davasse, B., Dubois, C., Izard, V., Métailié, J.P., 2002. Charcoal kilns and environmental history in the eastern Pyrenees (France). A methodological approach, in: Thiébault, S. (Ed.), Charcoal Analysis. Methodological Approaches, Palaeoecological Results and Wood Uses. BAR International Series. 1063: 219-228.

Bourquin-Mignot, C., Brochier, J.-E., Chabal, L., Crozat, S., Fabre, L., Guibal, F., Marinval, P., Richard, H., Terral, J.-F., Théry-Parisot, I., 1999. La Botanique. Collection Archéologiques, A. Ferdière (dir.), Errance Ed., France.

Briane, D., Doat, J., 1985. Guide technique de la carbonisation. La fabrication du charbon de bois. Édisud, Aix-en-Provence (France).

Castelletti L., 1990. Legni e carboni in Archeologia, in: Mannoni, T., Molinari, A., (Eds), Scienze in Archeologia, Firenze, pp. 321-394.

Cenzon-Salvayre, C., 2014. Le bûcher funéraire dans l'Antiquité : une approche archéologique, bioarchéologique et historique d'après l'étude des structures de crémation en Gaule méridionale. Ph.D. Thesis, University of Maine (France).

Chabal, L., 1982. Méthodes de prélèvement des bois carbonisés protohistoriques pour l'étude des relations homme-végétation. Diplôme d'Études Approfondies, University of Montpellier (France).

Chabal, L., 1988. Pourquoi et comment prélever les charbons de bois pour la période antique: les méthodes utilisées sur le site de Lattes (Hérault), In Mélanges d'Histoire et d'Archéologie de Lattes, A.R.A.L.O., M. Py (Ed.), Lattes. Lattara. 1: 187-222.

Chabal, L., 1989. Perspectives anthracologiques sur le site de Lattes (Hérault), In Introduction à l'étude de l'environnement de Lattes antique, A.R.A.L.O., M. Py (Ed.), Lattes. Lattara. 2: $53-72$.

Chabal, L., 1990. L'étude paléoécologique de sites protohistoriques à partir des charbons de bois : la question de l'unité de mesure. Dénombrement de fragments ou pesées ? in: Hackens, T., Munaut, A.V., Till, Cl. (Eds.), Wood and Archaeology. Bois et archéologie. First European Conference, Louvain-la-Neuve, Belgique, Oct. 2nd-3rd 1987. PACT. 22, pp. 189205.

Chabal, L., 1991. L'Homme et l'évolution de la végétation méditerranéenne, des âges des métaux à la période romaine : recherches anthracologiques théoriques, appliquées prncipalement à des sites du Bas-Languedoc. Ph.D. Thesis, University of Montpellier (France).

Chabal, L., 1992. La représentativité paléo-écologique des charbons de bois archéologiques issus du bois de feu, in: Vernet, J.-L. (Ed.), Les charbons de bois, les anciens écosystèmes et le rôle de l'Homme, Colloque International de Montpellier, 10-13 sept. 1991, Bull. de la Société botanique de France, Actualités Botaniques. 139 (2/3/4), pp. 213-236. 
Chabal, L., 1996. Le bois lié à l'architecture, in: Verdin, F. (Ed.), Coudounèu (Lançon-deProvence, Bouches-du-Rhône) : une ferme-grenier et son terroir au Ve siècle avant J.-C. Documents d'Archéologie Méridionale, vol. 19-20, pp. 166-172.

Chabal, L., 1997. Forêts et sociétés en Languedoc (Néolithique final, Antiquité tardive) : l'anthracologie, méthode et paléoécologie. Documents d'Archéologie Française. 63, 189 p.

Chabal, L., 2001. Les Potiers, le bois et la forêt à Sallèles d'Aude (I-IIIe s. ap. J.-C.), in: Laubenheimer, F. (Ed.), 20 ans de recherches à Sallèles d'Aude : le Monde des potiers galloromains, Colloque 27-28 Sept. 1996, Sallèles d'Aude, Presses Universitaires FrancComtoises, Série Amphores, pp. 93-110.

Chabal, L., Heinz, C., this issue. Reconstructing the heterogeneity of past woodlands in anthracology using the spatial distribution of charcoals in archaeological layers: applied to the postglacial occupation of the Abeurador cave (Hérault) in the south of France. Quaternary International.

Chabal, L., Laubenheimer, F., 1994. L'atelier gallo-romain de Sallèles d'Aude : les potiers et le bois, in : Actes des XIVe Rencontres Internationales d'Archéologie et d'Histoire d'Antibes Terre cuite et Société : la céramique, document technique, économique, culturel, APDCA ed., 21-23 oct. 1993, Juan-les-Pins, pp. 99-129.

Chabal, L., Vaschalde, C., in press. Évolution des espaces forestiers néolithiques et impact du pâturage en forêt : l'apport de l'anthracologie, in: C. Manen (Ed.). Le Taï (Remoulins, Gard). Premières sociétés agropastorales du Languedoc méditerranéen (6e-3e millénaire avant notre ère), Toulouse, Archives d'Ecologie Préhistorique.

Chrzazvez, J., Théry-Parisot, I., Fiorucci, G., Terral, J.-F., Thibaut, B., 2014. Impact of postdepositional processes on charcoal fragmentation and archaeobotanical implications: Experimental approach combining charcoal analysis and biomechanics. Journal of Archaeological Science. 44 (1): 30-42.

Collins C., Asouti E., Grove M., Kabukcu C., Bradley L., Chiverrell R., 2018. Understanding resource choice at the transition from foraging to farming: an application of palaeodistribution modelling to the Neolithic of the Konya Plain, south-central Anatolia, Turkey. Journal of Archaeological Science 96: 57-72.

Damblon, F. (Ed.) 2013. Proceedings of the fourth international meeting of Anthracology, 813 Sept. 2008, Brussels (Belgium). BAR International Series. 2486: 1-251.

Deforce, K., 2017. Wood use in a growing medieval city. The overexploitation of woody resources in Ghent (Belgium) between the 10th and 12th century AD. Quaternary International. 458: 123-133.

Delhon, C., 2018. Is choice acceptable? How the anthracological paradigm may hinder the consideration of fuel gathering as a cultural behaviour. Environmental Archaeology, 1-9.

Dufraisse, A., 2006. Charcoal analysis: new analytical tools and methods for archaeology. BAR International Series 1483. 
Dufraisse, A., 2008. Firewood management and woodland exploitation during the late Neolithic at Lac de Chalain (Jura, France). Vegetation History and Archaeobotany 17: 199210.

Dufraisse, A., Pétrequin, A. M., Pétrequin P., 2007. La gestion du bois de feu : un indicateur des contextes socio-écologiques. Approche ethnoarchéologique dans les Hautes Terres de Papua (Nouvelle-Guinée indonésienne), in : M. Besse (Ed.), Sociétés néolithiques. Des faits archéologiques aux fonctionnements socio-économiques, Cahiers d'archéologie romande, Lausanne 108 : 115-126.

Enes, T., Aranha, J., Fonseca, T., Lopes, D., Alves, A., Lousada, J., 2019. Thermal Properties of Residual Agroforestry Biomass of Northern Portugal. Energies. 12 (1418) : 1-13.

Fabre, L., 1996. Le Charbonnage historique de la chênaie de Quercus ilex L. (Languedoc, France) : conséquences écologiques. Ph.D. Thesis, University of Montpellier (France).

Fiorentino, G., Magri, D. (Eds.), 2008. Charcoals from the Past: Cultural and Palaeoenvironmental Implications. Proceedings of the Third International Meeting of Anthracology, Cavallino e Lecce (Italy), 28 June-1 July 2004. Archaeopress, Oxford.

Godron, M., 2012. Écologie et évolution du monde vivant. 3 volumes. L’Harmattan Ed., Paris.

Godwin, H., Tansley, A. G., 1941. Prehistoric charcoals as evidence of former vegetation, soil and climate. Journal of Ecology 19: 117-126.

Gotelli, N. J., Colwell, R. K., 2011. Estimating species richness. Biological diversity: frontiers in measurement and assessment, 12: 39-54.

Heinz, C., 1990a. Dynamique des végétations holocènes en Mediterranée occidentale d'après l'anthracoanalyse des sites préhistoriques : Méthodologie et Paléoécologie. Paléobiologie Continentale, XVI (2).

Heinz, C., 1990b. Méthodologie et paléoécologie du gisement préhistorique de l'Abeurador (Hérault) au passage Mésolithique/Néolithique, d'après l'analyse des charbons de bois : premiers résultats, in: Hackens, T., Munaut, A.V., Till, Cl. (Eds.), Wood and Archaeology. Bois et archéologie. First European Conference, Louvain-la-Neuve, Belgique, 2-3 Oct. 1987. PACT. 22, pp. 219-229.

Henry, A., 2011. Paléoenvironnements et gestion du bois de feu au Mésolithique dans le sudouest de la France : anthracologie, ethno-archéologie et expérimentation. Ph.D. Thesis, University of Nice-Sophia Antipolis, (France).

Henry, A., Coli, V. L., Valdeyron, N., Théry-Parisot, I., 2020. Old taphonomy issues, new charcoal data for Mesolithic contexts: Impact of fragment size and sampling context on the assemblages of Escabasses cave (SW France). Journal of Archaeological Science: Reports. 30: $1-10$. 
Henry, A., Valdeyron, N., Bouby, L., Théry-Parisot, I., 2013. History and evolution of Mesolithic landscapes in the Haut Quercy (Lot, France): new charcoal data from archaeological contexts. The Holocene. 23(1) : 127-136.

Izard, V., 1999. Les montagnes du fer : éco-histoire de la métallurgie et des forêts dans les Pyrénées méditerranéennes (de l'Antiquité à nos jours). Pour une histoire de l'environnement. Ph.D. Thesis, University of Toulouse (France).

Kabukcu, C., 2017. Woodland vegetation history and human impacts in south-central Anatolia 15,000-7000 cal. BP: Anthracological results from five prehistoric sites in the Konya Plain. Quaternary Science Reviews 176: 85-100.

Kabukcu, C., 2018a. Wood charcoal analysis in Archaeology, in : Pişkin, E., Marciniak, A., Bartkowiak, M. (Eds), Environmental Archaeology: Current Theoretical and Methodological Approaches. Springer, pp. 133-154.

Kabukcu, C., 2018b. Identification of woodland management practices and tree growth conditions in archaeological fuel waste remains: A case study from the site of Çatalhöyük in central Anatolia, Turkey. Quaternary International, 463: 282-297.

Kabukcu C., in press. Woodland vegetation and fuel use in the Konya plain of central Anatolia during the 9th millennium cal BC: anthracological remains from Boncuklu höyük. In: Baird D., Fairbairn A (eds) Boncuklu: First Farmers in Central Anatolia and the Antecedents of Çatalhöyük. from Foragers to Farmers in Central Anatolia Volume 1. London: British Institute at Ankara.

Keepax, C. A., 1988. Charcoal Analysis with Particular Reference to Archaeological Sites in Britain. Ph.D. Thesis, University of London.

Leney, L., Casteel, R. W., 1975 Simplified procedure for examining charcoal specimens for identification. Journal of Archaeological Science 2: 153-159.

Ludemann, T., 2010. Past fuel wood exploitation and natural forest vegetation in the Black Forest, the Vosges and neighbouring regions in western Central Europe. Palaeogeography, Palaeoclimatology, Palaeoecology. 291 (1-2): 154-165.

Ludemann, T., Nelle, O., 2002. Die Wälder am Schauinsland und ihre Nutzung durch Bergbau und Köhlerei. Forstliche Versuchs- und Forschungsanst. Freiburg (Breisgau): BadenWürttemberg.

Ludemann, T., Nelle, O. (Eds.), 2017-2018. Local to global significance of charcoal science, 6th International Anthracology Meeting, 20 Aug.-6 Sept. 2015, Freiburg (Germany). Quaternary International. 457, 458, 463B.

Marguerie, D., Hunot, J.-Y., 2007. Charcoal analysis and dendrology: data from archaeological sites in northwestern France. Journal of Archaeological Science 34: 14171433.

Martínez-Varea, C.M., Ferrer-Gallego, P.P., Raigón, M.D., Badal, E., Ferrando-Pardo, I., Laguna, E., Real, C., Roman, D., Villaverde, V., 2019. Corema album archaeobotanical 
remains in western Mediterranean basin. Assessing fruit consumption during Upper Palaeolithic in Cova de les Cendres (Alicante, Spain). Quaternary Science Reviews, 207: 112.

Moskal-del Hoyo, M., 2012. The use of wood in funerary pyres: random gathering or special selection of species? Case study of three necropolises from Poland. Journal of Archaeological Science, 39: 3386-3395.

Nelle, O., 2003. Woodland history of the last 500 years revealed by anthracological studies of charcoal kiln sites in the Bavarian Forest, Germany. Phytocoenologia. 33 (4): 667-682.

Nelle, O., Dreibrodt, S., Dannath, Y., 2010. Combining pollen and charcoal: evaluating Holocene vegetation composition and dynamics. Journal of Archaeological Science, 37(9): 2126-2135.

Ntinou, M., 2002. La Paleovegetación en el Norte de Grecia del Tardiglaciar hasta el Atlántico : formaciones vegetales, recursos y usos. BAR International Series. 1038.

Ntinou, M., Kyparissi-Apostolika, N. Local vegetation dynamics and human habitation from the last interglacial to the early Holocene at Theopetra cave, central Greece: the evidence from wood charcoal analysis. Vegetation History and Archaeobotany 25: 191-206.

Paradis-Grenouillet, S., 2012. Etudier les «forêts métallurgiques » : analyses dendroanthracologiques et approches géohistoriques Exemple des forêts du Mont Lozère et du Périgord-Limousin. Ph.D. Thesis, University of Limoges (France).

Paradis, S., Dufraisse, A., Allée, P., 2013. Radius of curvature measurements and wood diameter: a comparison of different image analysis techniques. In Damblon, F. (ed) Proceedings of the 4th International meeting of Anthracology. Brussels, 8-13 September 2008. Royal Belgian Institute of Natural Sciences, 173-182. BAR International Series 2486.

Pearsall, D. M., 2000. Paleoethnobotany: A Handbook of Procedures. 2nd Ed. San Diego: Academic Press.

Pernaud, J.-M., 1992. L'interprétation paléoécologique des charbons concentrés dans les fosses-dépotoirs protohistoriques du Carrousel (Louvre, Paris). Bulletin de la Société Botanique de France, Actualités Botaniques. 139 (2-4) : 329-341.

Picornell-Gelabert, L., 2020. An archaeological approach to people-tree interactions: The ethnoarchaeology of firewood procurement and consumption among the Benga people of the island of Mandji (Corisco, Equatorial Guinea, Central Africa). Journal of Archaeological Science: Reports, 34, p.102591.

Picornell-Gelabert, L., Asouti, E., and Martí, E. A., 2011. The ethnoarchaeology of firewood management in the Fang villages of Equatorial Guinea, central Africa: implications for the interpretation of wood fuel remains from archaeological sites. Journal of Anthropological Archaeology, 30(3): 375-384. 
Py, V., 2009. Mine, bois et forêt dans les Alpes du Sud au Moyen Âge. Approches archéologique, bioarchéologique et historique. Ph.D. Thesis, University of Aix-Marseille (France).

Py, V., Durand, A., Ancel, B., 2013. Anthracological analysis of fuel wood used for firesetting in medieval metallic mines of the Faravel district (southern French Alps). Journal of Archaeological Science. 40, 3878-3889.

Roberts, N., Woodbridge, J., Bevan, A., Palmisano, A., Shennan, S., Asouti, E., 2018. Human responses and non-responses to climatic variations during the last Glacial-Interglacial transition in the eastern Mediterranean. Quaternary Science Reviews, 184: 47-67.

Rossen, J., Olson, J., 1985. The controlled carbonisation and archaeological analysis of SE U.S. wood charcoals. Journal of Field Archaeology. 12: 445-456.

Salisbury, K. J., Jane, F. W., 1940. Charcoals from Maiden Castle and their significance in relation to the vegetation and climatic conditions in prehistoric times. Journal of Ecology 28: 310-325.

Scheel-Ybert, R., 1998. Stabilité de l'écosystème sur le littoral Sud-Est du Brésil à l'Holocène Supérieur (5500-1400 ans BP). Les pêcheurs-cueilleurs-chasseurs et le milieu végétal : apports de l'anthracologie. Ph.D. Thesis, University of Montpellier (France).

Scheel-Ybert, R., 2002. Evaluation of sample reliability in extant and fossil assemblages, in: Thiébault, S. (Ed.), Charcoal Analysis. Methodological Approaches, Palaeoecological Results and Wood Uses. BAR International Series. 1063: 9-16.

Smart, T.L., Hoffman, E.S., 1988. Environmental Interpretation of Archaeological Charcoal, in: Hastorf, C.A. and Popper V.S., Current Paleoethnobotany, Analytical Methods and Cultural Interpretations of Archaeological Plant remains. Prehistoric Archeology and Ecology Series, Chicago, 167-205.

Stirling, P., 1965. A Turkish Village. New York: Wiley.

Théry-Parisot, I., 2001. Économie du combustible au Paléolithique. Anthracologie, Expérimentation, Taphonomie, CEPAM, CNRS Editions.

Théry-Parisot, I., Chabal, L., J. Chrzavzez, 2010a. Anthracology and taphonomy, from wood gathering to charcoal analysis. A review of the taphonomical processes modifying anthracological assemblages in archaeological contexts. Palaeogeography, Palaeoclimatology, Palaeoecology. 291: 142-153.

Théry-Parisot, I., Chabal, L., Ntinou, M., Bouby, L., Carré, A., 2010b. Du bois aux charbons de bois : approche expérimentale de la combustion. From wood to wood charcoal: an experimental approach to combustion, in: I. Théry-Parisot, L. Chabal, S. Costamagno (Eds.), Actes de la table ronde internationale Taphonomie de la combustion des résidus organiques et des structures de combustion en contexte archéologique, 27-29 mai 2008, Valbonne.

Palethnology. 2: 81-93. 
Thiébault, S. (Ed.), 2002. Charcoal analysis: Methodological approaches, palaeoecological results and wood uses. BAR International Series. 1063.

Vaschalde, C., 2018. Fours à chaux et chaufourniers en France méditerranéenne au Moyen âge et à l'époque moderne. Approche interdisciplinaire autour des techniques, des savoir-faire et des artisans, coll. Europe médiévale 14, Drémil-Lafage, éditions Mergoil.

Vaschalde, C., Chabal, L., in press. Production du combustible pour l'atelier de potiers de Contours (Saint-Pargoire, Hérault) au cours du Haut Empire, d'après l'anthracologie et la dendrométrie : exploitation par rotation des taillis de chênes méditerranéens, in: Mauné, S., (Dir.), L'atelier de Contours à Saint-Pargoire (Hérault), Editions Monique Mergoil.

Vernet, J.-L. (Ed.), 1992. Les charbons de bois, les anciens écosystèmes et le rôle de l'homme. Actes du Colloque. Bulletin de la Société Botanique de France, Actualités Botaniques. 139 (2/3/4).

Western, A. C., 1971. The ecological interpretation of ancient charcoals from Jericho. Levant 3: 31-40. 